\title{
Spatiotemporal Variability in Environmental Conditions Influences the Performance and Behavior of Juvenile Steelhead in a Coastal California Lagoon
}

\author{
Rosealea M. Bond ${ }^{1}$ (1) . Joseph D. Kiernan ${ }^{2,3}$ (1) - Ann-Marie K. Osterback ${ }^{1}$ (i) . Cynthia H. Kern ${ }^{1} \cdot$ Alexander E. Hay $^{1}$. \\ Joshua M. Meko ${ }^{1}$ - Miles E. Daniels ${ }^{1}$ D . Jeffrey M. Perez ${ }^{1}$
}

Received: 16 February 2021 / Revised: 13 October 2021 / Accepted: 20 October 2021 / Published online: 25 November 2021

(c) The Author(s) 2021

\begin{abstract}
In California (USA), seasonal lagoons provide important oversummer rearing habitat for juvenile steelhead trout (anadromous Oncorhynchus mykiss). However, key water quality parameters such as temperature and dissolved oxygen concentration can periodically approach or exceed the physiological tolerances of steelhead during the protracted dry season. A field study employing distributed temperature sensing technology, water quality monitoring, habitat mapping, and mark-recapture sampling was conducted to examine how shifting environmental conditions affected the performance and behavior of juvenile steelhead in the Scott Creek estuary/lagoon (Santa Cruz County). Abiotic conditions were driven by episodic inputs of seawater to the typically freshwater lagoon. During midsummer, the water column was vertically stratified which reduced suitable lagoon rearing habitat by approximately $40 \%$. Nevertheless, steelhead abundance, growth, and condition factor were high during the summer and decreased in autumn following lagoon destratification and cooling. Unlike previous work, this study identified limited emigration from the lagoon to riverine habitat during the summer. Instead, juvenile steelhead exhibited crepuscular movement patterns within the lagoon, with peaks in upstream (to upper lagoon habitat) and downstream (to lower lagoon habitat) movement occurring at dawn and dusk, respectively. This study underscores that habitat complexity and connectivity are critical for juvenile steelhead production and persistence and provides insight into steelhead habitat use and behavior in seasonal lagoons.
\end{abstract}

Keywords Bar-built estuary $\cdot$ Distributed temperature sensing $\cdot$ Critical habitat $\cdot$ Endangered species $\cdot$ Climate change

Communicated by Ronald Baker

Rosealea M. Bond and Joseph D. Kiernan contributed equally to this work.

Rosealea M. Bond

lea.bond@noaa.gov

1 Fisheries Collaborative Program, Institute of Marine Sciences, University of California, Santa Cruz, Affiliated With Southwest Fisheries Science Center, National Marine Fisheries Service, National Oceanic and Atmospheric Administration, 110 McAllister Way, Santa Cruz, CA 95060, USA

2 Fisheries Ecology Division, Southwest Fisheries Science Center, National Marine Fisheries Service, National Oceanic and Atmospheric Administration, 110 McAllister Way, Santa Cruz, CA 95060, USA

3 Institute of Marine Sciences, University of California, Santa Cruz, 1156 High Street, Santa Cruz, CA 95064, USA

\section{Introduction}

In many areas of the world, coastal estuaries periodically lose connectivity with the marine environment due to the formation of seasonal sandbars (barrier beaches) at their tidal mouths (Lill et al. 2013). Termed bar-built estuaries (Emmett et al. 2000), sandbar formation predominantly occurs during the dry season when reduced fluvial discharge coincides with increased ocean swell intensity and longshore sand deposition (Behrens et al. 2013; Clark and O'Connor 2019). Freshwater discharge from the drainage network is subsequently impounded behind the sandbar and the estuary converts to a seasonal lagoon. Although the timing and duration of river mouth closures are highly variable from year to year, lagoonal conditions can persist for weeks to months until the sandbar is eroded by high energy waves and (or) elevated streamflow, and connectivity with the marine 
environment is reestablished (Smith 1990; Behrens et al. 2013; Nylen 2015).

In California (USA), nearly half of the state's coastal river mouths are influenced by seasonal sandbar formation to varying degrees (Heady et al. 2015; Clark and O'Connor 2019). Following mouth closure, estuaries often transition through multiple ecological states due to episodic changes in key environmental parameters such as lagoon volume, water temperature, dissolved oxygen (DO) concentration, and salinity (Shapovalov and Taft 1954; Boughton et al. 2017). While freshwater predominates, conditions can become brackish when occasional large waves overtop the beach crest and deliver seawater into the lagoon (Smith 1990; Nylen 2015; Osterback et al. 2018). Episodic overtopping events can substantially alter lagoon water chemistry and result in stratified conditions (both vertical and longitudinal) which can last days to months at a time depending on lagoon bathymetry and the volume of freshwater inflow delivered from the watershed (Behrens et al. 2013, 2016; Nylen 2015). Consequently, abiotic conditions can periodically approach or exceed the physiological tolerances of some lagoon-rearing organisms. There is growing concern that periods of extreme environmental conditions may become increasingly commonplace due to habitat alteration and climate warming (Richards et al. 2018; Crozier et al. 2019), with adverse consequences for native fishes that use estuaries and lagoons as part of their life history strategies (Moyle et al. 2013; National Marine Fisheries Service 2012, 2016).

For juvenile steelhead trout (anadromous Oncorhynchus mykiss), seasonal lagoons have been characterized as high-risk, high-reward rearing habitat (Satterthwaite et al. 2012). Despite representing a small fraction of the oversummer rearing habitat in most coastal California watersheds (Bond et al. 2008), lagoon rearing may confer significant fitness advantages due to abundant prey resources and high growth potential. Hayes et al. (2008) reported that summer and autumn weekly growth rates were significantly (6- to 17-fold) higher for lagoon-rearing juvenile steelhead relative to conspecifics rearing in upstream riverine habitat. Additionally, empirical studies have demonstrated that lagoonrearing juvenile steelhead often attain critical size for ocean entry (fork lengths $>150 \mathrm{~mm}$ ) at a relatively early age, experience enhanced marine survival, and disproportionately recruit to the adult breeding population (Bond et al. 2008; Hayes et al. 2011). However, lagoons may expose juvenile steelhead to elevated predation risk (Hayes et al. 2011; Frechette et al. 2013; Osterback et al. 2013) and periods of physiological stress due to degraded water quality (Smith 1990; Boughton et al. 2017; Osterback et al. 2018).

Recently, Osterback et al. (2018) provided evidence that juvenile salmonids (both steelhead and the more thermally sensitive coho salmon, Oncorhynchus kisutch) were able to survive and add substantial body mass in the Scott Creek
(Santa Cruz County, CA, USA) lagoon during an extended (>7 months) drought-related closure event, despite periods of high water temperature $\left(>20^{\circ} \mathrm{C}\right)$ and hypoxia $(\mathrm{DO}<5$ $\left.\mathrm{mg} \mathrm{L}^{-1}\right)$. It remains unclear, however, how juvenile salmonids cope with such extremes when they occur. Based on previous works (e.g., Bond et al. 2007; Hayes et al. 2011) and additional data, Osterback et al. (2018) hypothesized that juvenile salmonid persistence was likely facilitated by alternating upstream movement to cooler riverine habitat and downstream movement to the prey-rich lower lagoon.

To test this upstream-downstream movement hypothesis, we intensively monitored a $1.5-\mathrm{km}$ segment of lower Scott Creek through the full period of creek mouth closure and lagoon formation during the 2018 dry season (late June-November). Our study area encompassed the estuary/lagoon, lagoon-river transition zone, and lower mainstem riverine habitat, thus permitting an assessment of how spatiotemporal patterns in abiotic conditions related to the behavior and performance of juvenile steelhead during the annual dry period. Our goals were to (1) characterize finegrained spatiotemporal dynamics of key physical habitat and water quality parameters throughout the lagoon and lower mainstem creek; (2) quantify the response of lagoon-rearing juvenile steelhead in terms of monthly abundance, growth, and condition; and (3) quantify the response of juvenile steelhead in terms of movement within and among estuary/ lagoon and riverine habitats.

\section{Methods}

\section{Study Site}

The Scott Creek watershed is a small (watershed area $=70$ $\mathrm{km}^{2}$ ) coastal drainage located approximately $90 \mathrm{~km}$ south

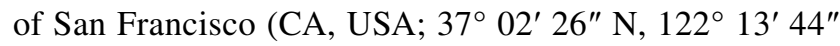
W; Fig. 1). The climate is cool Mediterranean with mean air temperatures ranging from approximately $10{ }^{\circ} \mathrm{C}$ during the winter to $17^{\circ} \mathrm{C}$ during the summer. Summer temperatures are tempered by recurrent coastal fog and low cloud cover. Rainfall patterns produce an annual hydrograph characterized by episodic spates $\left(>35 \mathrm{~m}^{3} \mathrm{~s}^{-1}\right)$ during winter and spring, followed by a protracted period of low streamflow $\left(<0.1 \mathrm{~m}^{3} \mathrm{~s}^{-1}\right)$ throughout summer and autumn. While instantaneous water temperatures rarely exceed $20^{\circ} \mathrm{C}$ in lotic portions of the watershed, the small exposed estuary at the terminus of the drainage network is prone to summer heating and water temperatures can exceed $24{ }^{\circ} \mathrm{C}$ (Hayes et al. 2008; Osterback et al. 2018). The Scott Creek freshwater fish assemblage is entirely native and composed of coho salmon, steelhead, threespine stickleback (Gasterosteus aculeatus), prickly sculpin (Cottus asper), and coastrange sculpin (Cottus aleuticus). Pacific staghorn sculpin (Leptocottus 


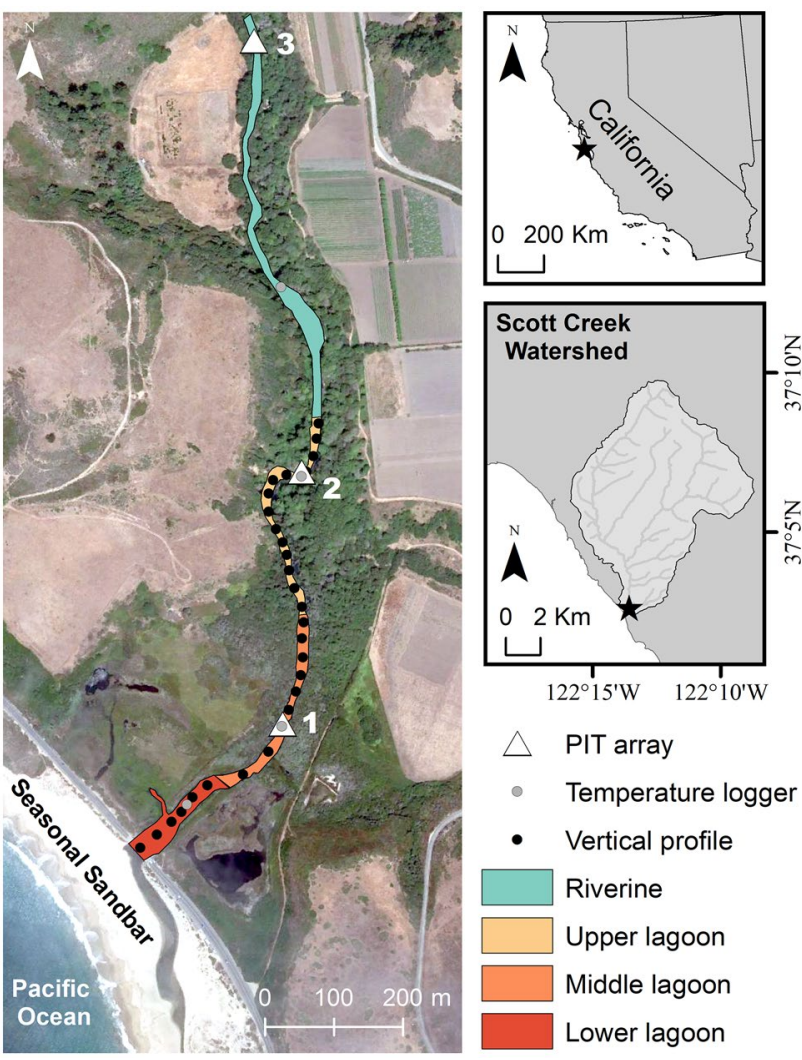

Fig. 1 Location map of the Scott Creek (Santa Cruz County, CA, USA) watershed and a detailed view of the four sample reaches in the $1.5-\mathrm{km}$ study segment. Numbers refer to the Lagoon (1), Interface (2), and Riverine PIT tag antenna arrays (3). Water downstream of the California State Route 1 bridge was too shallow for sampling and was excluded from the study. Satellite image credit: Google Earth; 9 August 2018

armatus) and tidewater goby (Gobius newberryi) are estuarine residents, and juvenile starry flounder (Platichthys stellatus) are occasionally present. Both tidewater goby and coho salmon (central California coast evolutionarily significant unit) are listed as endangered under the US Endangered Species Act (ESA), while steelhead (central California coast distinct population segment) is listed as a threatened species.

Scott Creek is representative of most small coastal watersheds in California, in that its estuary converts to a lagoon for many months during the annual dry season due to the formation of a sandbar at the creek mouth that severs connectivity with the Pacific Ocean. Between 2003 and 2017, the average annual dates of creek mouth closure (i.e., sandbar formation) and reopening were 17 July (day of year $[D O Y]=198)$ and 29 November $(\mathrm{DOY}=333)$, respectively. Data collection in support of this study was initiated on 20 June 2018, prior to mouth closure on 5 July $(\mathrm{DOY}=186$ ) and was terminated on 20 November 2018 prior to the first major rainfall event (the sandbar naturally breached due to elevated discharge on 30 November, DOY =334). Thus, our study characterized nearly the full range of environmental conditions in the Scott Creek estuary/lagoon immediately preceding and during mouth closure in a typical annual open-close cycle.

\section{Study Design}

We focused on a 1.5-km segment of lower Scott Creek that encompassed both estuarine and riverine habitat. The study segment was partitioned into four contiguous sample reaches based on salient changes in geomorphic and (or) environmental conditions: (1) the lower lagoon sample reach extended from the California State Route 1 bridge (designated as river kilometer [rkm] 0.0 in our study) upstream to where adjacent wetland vegetation transitioned from marsh plants to low scrub ( rkm 0.17); (2) the middle lagoon sample reach extended from rkm 0.17 to the confluence with an ephemeral tributary known locally as Queseria Creek ( rkm 0.48); (3) the upper lagoon sample reach extended from Queseria Creek to the lagoon-river transition zone; and (4) the riverine sample reach extended from the lagoon-river transition zone upstream to rkm 1.48 (Figs. 1, 2). We defined the extent of lagoon inundation as the distance upstream from rkm 0.0 to the first riffle in which there was a break in water surface elevation; this location ranged from rkm 0.72 to 0.83 during the study period.

\section{Field Methods}

\section{Physical Habitat Characterization}

To quantify physical habitat conditions within the estuary/ lagoon, we established 28 sampling transects oriented perpendicular to the longitudinal axis of the stream channel. Transects began at rkm 0.0 and extended upstream (inland) at irregularly spaced intervals (interval range $=25-40 \mathrm{~m}$ ) to the maximum extent of inundation during the study period (rkm 0.83; Fig. 1). At each lagoon transect, we measured wetted width $( \pm 0.1 \mathrm{~m})$, maximum depth $( \pm 0.1 \mathrm{~m})$, and determined percentage shading $( \pm 1.0 \%)$ using a Solar Pathfinder ${ }^{\mathrm{TM}}$ (Solar Pathways, Colorado Springs, CO, USA) positioned at the water surface directly above the point of maximum depth.

To characterize physical habitat conditions within the riverine sample reach, up to 31 mesohabitat units were designated as riffle, run, or pool according to water depth and surface velocity. The number of riverine habitat units likewise varied during the study due to changes in the upstream extent of lagoon inundation. For each riverine habitat unit, we quantified unit length $( \pm 0.1 \mathrm{~m})$, mean wetted width $( \pm 0.1 \mathrm{~m})$, and maximum depth $( \pm 0.1 \mathrm{~m})$. Percentage shading was measured every $25 \mathrm{~m}$ along the thalweg. For riverine pool habitats, we report depth as residual pool depth, 
calculated as the difference in streambed elevation between the deepest point in the pool and the downstream riffle crest (Lisle 1987). Physical habitat sampling was conducted monthly within $48 \mathrm{~h}$ of each fish sampling event (see Methods: "Fish Capture and Tagging").

\section{Water Quality}

We continuously measured water temperature $\left({ }^{\circ} \mathrm{C}\right)$ in each of the four sample reaches (Fig. 1) using TidbiT ${ }^{\circledR}$ v2 data loggers (Onset Computer Corporation, Bourne, MA, USA). The temperature loggers were positioned in the water column at a height $0.3 \mathrm{~m}$ above the bottom and programmed to record every $15 \mathrm{~min}$. To determine longitudinal and vertical patterns in water quality, we generated monthly vertical profiles of temperature, DO $\left(\mathrm{mg} \mathrm{L}^{-1}\right)$, and salinity (\%o) at each lagoon transect, using a YSI 556 handheld multi-probe system (Yellow Springs Instruments Inc., Yellow Springs, OH, USA). Vertical profile sampling was conducted from downstream to upstream at the point of maximum depth along each transect and characterized the entire water column at $10-\mathrm{cm}$ intervals. Profile sampling was conducted from a kayak during daytime hours (10:00-15:00 h) over a 1-2-day period and occurred just prior to each fish sampling event.

\section{High-resolution Distributed Temperature Sensing}

We used a multi-channel distributed temperature sensing (DTS) instrument (XT-DTS ${ }^{\text {TM }}$, Silixa Ltd., Elstree, Hertfordshire, UK) and spliced fiber-optic cable (PS-2S2M3PA038-01, Silixa Ltd.) to continually characterize the near-bottom thermal regime in the study segment. DTS instruments function as densely spaced linear sensors via the fiber-optic cable, producing temperature datasets with high spatial and temporal resolution (Selker et al. 2006a, b; Tyler et al. 2009). We deployed approximately $1.6 \mathrm{~km}$ of fiber-optic cable starting at the upstream end of the riverine sample reach ( $\mathrm{rkm} \mathrm{1.48)}$ and terminating in the lower lagoon (rkm 0.13) immediately adjacent to our fish sampling area. The DTS was deployed in a "duplexed single-ended" configuration with the instrument stationed upstream (streamside at rkm 1.48) and accompanied by two sequential calibration baths (Hausner et al. 2011; Bond et al. 2015). The DTS instrument collected data every $10 \mathrm{~min}$ at $25-\mathrm{cm}$ intervals per channel along the entire length of the fiber-optic cable. Eight TidbiT® v2 temperature data loggers were installed along the length of the cable for calibration and validation (Hausner et al. 2011; Bond et al. 2015).

\section{Fish Capture and Tagging}

To generate monthly estimates of juvenile steelhead abundance, growth, and condition factor, we conducted mark-recapture sampling in the lower lagoon sample reach (i.e., rkm 0.0-0.17) between July and November 2018. Fish sampling occurred on two consecutive days each month, whereby the first day served as the mark event and the second day the recapture event. This approach resulted in 10 sampling occasions over the 5-month study period. Juvenile steelhead were captured using a nylon beach seine ( 35 $\mathrm{m}$ long $\times 2.0 \mathrm{~m}$ deep), following the methods described by Osterback et al. (2018). Sampling effort was standardized on each occasion and consisted of seven seine hauls in the sampling area. Based on the work of Cowley and Whitfield (2001), we assumed that fish had sufficient time to redistribute and mix between each sampling occasion; thus, capture probabilities were homogeneous on each date. All captured steelhead were counted, measured for fork length $(\mathrm{FL} ; \pm 1.0$ $\mathrm{mm}$ ), and scanned for the presence of a passive integrated transponder (PIT) tag. Some captured individuals had been PIT-tagged prior to our study in support of ongoing research and monitoring, and these individuals were retained in the dataset. A subset of previously untagged juvenile steelhead $\geq 65 \mathrm{~mm}$ FL (the minimum size for PIT tagging) were anesthetized with buffered tricaine methanesulfonate (MS222; Western Chemical Inc., Ferndale, WA, USA), measured for FL and mass $( \pm 0.1 \mathrm{~g})$, and implanted with PIT tags (12 mm HDX tag; Oregon RFID Inc., Portland, OR, USA) via intraperitoneal injection. Implicit in all PIT tagging studies is the assumption that the performance and behavior of tagged individuals will be unbiased and representative of the broader (untagged) population. The capture and handling of ESA-listed steelhead was authorized by the National Marine Fisheries Service under Sect. 10(a)(1)(A) permit No. 17292-2A. All procedures were carried out in accordance with approved protocols from the Institutional Animal Care and Use Committee at University of California Santa Cruz (Protocol No. KIERJ1604_A1).

\section{Movement Behavior of PIT-Tagged Individuals}

To monitor the movement behavior of PIT-tagged juvenile steelhead during the study period, we operated three PIT tag interrogation stations (Multi-antenna HDX readers; Oregon RFID Inc.) within our $1.5-\mathrm{km}$ study segment. The three stations, identified as the Lagoon Array, Interface Array, and Riverine Array, were located at rkm 0.30 (near the midpoint of the lagoon), rkm 0.72 (near the lagoon-riverine interface), and $\mathrm{rkm} 1.42$ (in mainstem riverine habitat), respectively (Fig. 1). Each array consisted of paired swim-through antennas that were separated by $\sim 3.0 \mathrm{~m}$ and spanned the entire channel width. The clocks and scan-cycles of all stations were synchronized over the study period; thus, we were able to quantify the timing and extent of movement by juvenile steelhead within and among lagoon and riverine habitats. We hypothesized (1) the Interface Array would detect elevated 
rates of upstream movement (i.e., to riverine habitat) when conditions within the estuary/lagoon became physiologically stressful for juvenile steelhead, and (2) the timing of directional fish movement over a diel ( $24 \mathrm{~h})$ cycle at each station would be non-random.

\section{Data Analysis}

\section{Temperature Datasets}

Time series data generated by the temperature loggers in each sample reach (Fig. 1) were converted to 7-day moving averages of daily maximum temperature values to derive maximum weekly maximum temperature (MWMT; i.e., the highest mean value obtained across the entire study period). MWMT is a common metric for characterizing differences in thermal maxima in salmon-bearing ecosystems (e.g., United States Environmental Protection Agency 2003). Postprocessing of DTS data was conducted in the MATLAB ${ }^{\circledR}$ (The MathWorks, Natrick, MA, USA) computing environment using the DTS Toolbox produced by the Center for Transformative Environmental Monitoring Programs (https:// ctemps.org/data-processing, last accessed 1 October 2021). We followed the "three-section explicit with step loss" method (Hausner et al. 2011), whereby data from each channel were calibrated against two known points (calibration baths) and validated against a third set of points (temperature loggers affixed to the fiber-optic cable). Diagnostic statistics indicated both validation root mean square error (0.39) and validation bias (0.14) were within the ranges reported in other aquatic field applications using single-ended measurements (e.g., Hausner et al. 2011).

\section{Steelhead Abundance, Growth, and Condition Factor}

Estimates of juvenile steelhead abundance were generated for each monthly mark-recapture event using the POPAN formulation of the Jolly-Seber model (Schwarz and Arnason 1996) within Program MARK (White and Burnham 1999). Parameters included in POPAN to estimate abundance at each sampling occasion included (1) probability of survival $(\phi) ;(2)$ probability of capture $(p)$; (3) probability of entry $(\beta)$; and (4) super-population size ( $N^{*}$; Schwarz and Arnason 1996; Williams et al. 2011). We initialized the model with a combination of PIT-tagged and untagged fish, the latter considered losses on capture (Frechette et al. 2016). This approach allowed us to include all captured individuals in the model without the cost and burden of physically marking (i.e., PIT tagging) every fish. However, because untagged individuals may have unknowingly been handled multiple times during the study period, the super-population estimate generated by the POPAN model is potentially inflated (Malcolm-White et al. 2020) and not presented herein. Rather, we focus on the estimates of steelhead abundance generated for each sampling occasion which were expected to be unbiased (Schwarz and Arnason 1996; Frechette et al. 2016; Osterback et al. 2018). The candidate POPAN model set included four models: (1) the probabilities of survival, capture, and entry were allowed to vary over time $\left(\phi_{(t)} p_{(t)} \beta_{(t)} N^{*}\right) ;(2)$ the probabilities of capture and entry were allowed to vary over time while the probability of survival was held constant over time $\left(\phi_{(.)} p_{(t)} \beta_{(t)} N^{*}\right)$; (3) the probabilities of survival and entry were allowed to vary over time while the probability of capture was held constant over time $\left(\phi_{(t)} p_{(.)} \beta_{(t)} N^{*}\right)$; and (4) a null model in which both survival and capture were held constant over time and the probability of entry was allowed to vary over time $\left(\phi_{(.)} p_{(.)} \beta_{(t)} N^{*}\right)$. To assess POPAN model fit, we applied a chi-square $\left(\chi^{2}\right)$ goodness-of-fit test to the saturated model using Program RELEASE within Program MARK. If lack of fit was identified, we assumed it was due to overdispersion of captures and a variance inflation factor $(\widehat{c})$ was applied to the model set. The variance inflation factor was calculated using the $\chi^{2}$ test statistic and degrees of freedom $(d f)$ obtained from Program RELEASE (Cooch and White 2021; Sect. 5.5.1) using the equation:

$\widehat{c}=\frac{\chi^{2}}{d f}$

Model selection was performed using quasi-Akaike's Information Criterion adjusted for small sample size (QAIC ${ }_{\mathrm{c}}$; Lebreton et al. 1992).

We calculated the mass-specific growth rates (MSGR) of PIT-tagged individuals captured in consecutive months using the formula:

$$
\operatorname{MSGR}=\frac{M_{2}^{b}-M_{1}^{b}}{b \times d} \times 100
$$

where $M_{2}$ is the final wet mass ( $\left.\mathrm{g}\right), M_{1}$ is the initial wet mass (g), $d$ is the growth interval (days), and $b$ is the allometric mass exponent for the relationship between fish growth rate and wet mass (Ostrovsky 1995). We used $b=0.34$ derived from empirical studies of $O$. mykiss (Wangila and Dick 1988). MSGR standardizes growth across size ranges and is reported as the percentage change in mass per gram of body mass per day $\left(\% \mathrm{~g}^{-1} \mathrm{day}^{-1}\right)$. The determination of MSGR for individuals captured in July was made possible by sampling conducted in the lagoon in early June (6-8 June 2018), prior to sandbar closure and the initiation of lagoon conditions.

Condition factor $(K)$ was calculated for a subset of steelhead captured during each sampling as:

$K=\frac{M \times 10^{5}}{L^{3}}$ 
Table 1 Mean physical habitat characteristics ( \pm standard error) for the four sample reaches during monthly sampling of Scott Creek (CA, USA), during the 2018 dry season (JulyNovember)

\begin{tabular}{|c|c|c|c|c|}
\hline \multirow[t]{2}{*}{ Variable } & \multicolumn{4}{|l|}{ Sample reach } \\
\hline & Lower lagoon & Middle lagoon & Upper lagoon & Riverine \\
\hline Number of transects ${ }^{\mathrm{a}}$ & 5 & 9 & $10-14$ & $24-31$ \\
\hline Reach length $(\mathrm{m})^{\mathrm{a}}$ & 173.6 & 309.3 & $346.3 \pm 28.0$ & $655.9 \pm 20.4$ \\
\hline Reach area $\left(\mathrm{m}^{2}\right)$ & $5,165.9 \pm 86.6$ & $5,133.7 \pm 68.3$ & $3,947.7 \pm 286.4$ & $3,816.0 \pm 255.8$ \\
\hline Wetted width (m) & $28.4 \pm 0.2$ & $16.6 \pm 0.1$ & $10.5 \pm 0.2$ & $5.8 \pm 0.1$ \\
\hline Shade $(\%)$ & $19.6 \pm 6.7$ & $41.2 \pm 4.9$ & $71.1 \pm 3.2$ & $87.7 \pm 1.7$ \\
\hline Maximum depth (m) & $2.1 \pm 0.02$ & $1.6 \pm 0.02$ & $1.0 \pm 0.04$ & -- \\
\hline Residual pool depth (m) & -- & -- & -- & $0.7 \pm 0.04$ \\
\hline Riffle by length (\%) & -- & -- & -- & $13.9 \pm 0.5$ \\
\hline Run by length (\%) & -- & -- & -- & $8.7 \pm 1.3$ \\
\hline Pool by length (\%) & -- & -- & -- & $77.3 \pm 1.7$ \\
\hline
\end{tabular}

${ }^{a}$ Variability in the number of sampling transects and reach length is due to changes in the upstream extent of lagoon inundation (i.e., location of the lotic/lentic interface) during the study period where $M$ is wet mass $(\mathrm{g})$ and $L$ is fork length (mm). Differences in monthly $K$ and square root transformed MSGR were assessed using one-way analysis of variance (ANOVA) followed by post hoc tests using Tukey's honest significant difference (HSD). Statistical analyses were performed in the R statistical environment (R Development Core Team 2019).

\section{PIT Tag Detection Data}

Raw PIT tag detection data were screened and processed following the methods described by Osterback et al. (2018) to remove milling behavior and (or) residency, and to identify directional movement events. We
Fig. 2 Representative habitat characteristics for the four sample reaches in the Scott Creek (CA, USA) watershed (a) lower lagoon, (b) middle lagoon, (c) upper lagoon, and (d) riverine sample reaches. All photos taken facing upstream
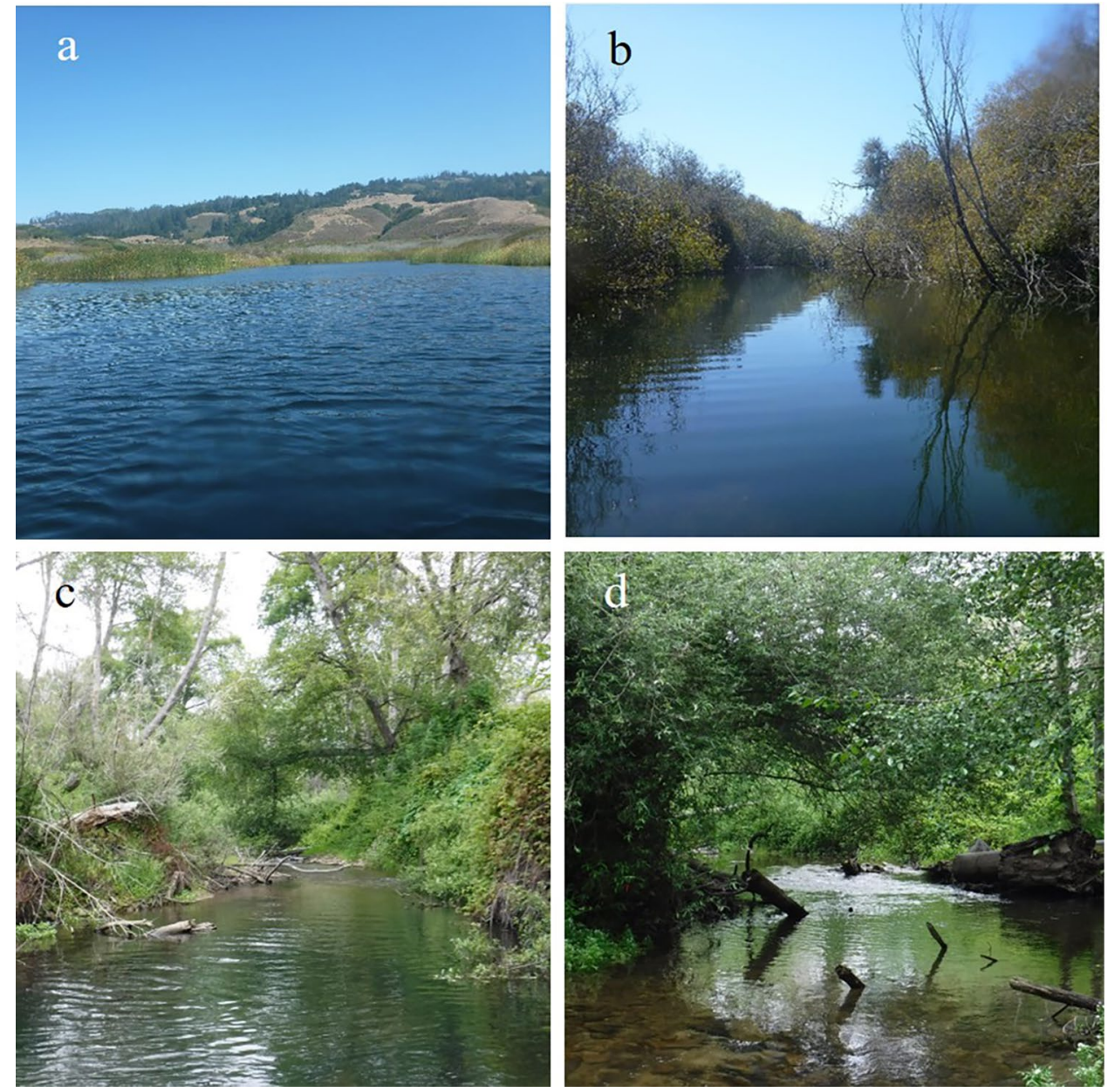
subsequently assigned "upstream" or "downstream" directionality to each fish movement event based on serial detections and categorized an event as "ambiguous" with respect to directionality when a detection only occurred on one of the paired antennas. To examine diel movement patterns, we employed two statistical tests using the circular package in R (Agostinelli and Lund 2017). First, we used the Hermans-Rasson test to assess whether the distribution of upstream or downstream movements differed significantly from uniformity over a diel cycle (Landler et al. 2019). Second, we used the non-parametric Mardia-Watson-Wheeler test (Batschelet 1981) to examine whether diel activity patterns (i.e., mean time of day) differed for upstream and downstream movement during the study. Additionally, we plotted directional movement data relative to sunlight conditions, categorized as night, dawn, day, or dusk based on local sunrise and sunset information for each day of the study (United States Naval Observatory 2011). We defined dawn and dusk as the periods $2.5 \mathrm{~h}$ before sunrise and after sunset, respectively.

\section{Results}

\section{Reach Scale Habitat Characteristics}

The four sample reaches represented a longitudinal gradient in habitat size and complexity. During the study, the lower lagoon reach had the greatest wetted width (mean $\pm \mathrm{SE}=28.4 \pm 0.2 \mathrm{~m})$ and depth $(2.1 \pm 0.02 \mathrm{~m})$, and these habitat parameters decreased in each successive sample reach moving inland (Table 1). Conversely, mean shading increased fourfold in the same direction, from $19.6 \pm 6.7 \%$ in the lower lagoon sample reach to $87.7 \pm 1.7 \%$ in the riverine sample reach (Table 1). The gradient in shading reflected a general upstream reduction in channel width, coupled with a shift in adjacent terrestrial plant communities from emergent marsh plants in the lower lagoon sample reach, to coastal scrub in the middle lagoon sample reach, and ultimately to tall woody riparian species in the upper lagoon and riverine sample reaches (Fig. 2). Pools were the dominant mesohabitat type within the riverine sample reach and pool units were highly variable in size (monthly mean residual depth $=0.7 \pm 0.04 \mathrm{~m}$, range $0.2-1.7 \mathrm{~m}$; Table 1 ).

\section{Spatiotemporal Variability in Abiotic Conditions}

DTS, temperature logger, and vertical profile data were used to identify four distinct environmental phases in the development and evolution of the Scott Creek lagoon during our 154-day study. The first 23 days (20 June-12 July; phase 1) encompassed sandbar formation on 5 July and conversion of the tidally influenced estuary into lagoonal conditions. During the beginning of phase 1 , mean water temperatures were similar across the four sample reaches owing to predominantly lotic conditions and the conveyance of $\operatorname{cool}\left(\sim 16.0^{\circ} \mathrm{C}\right)$ freshwater from upstream (Figs. 3 and 4a-c, Table 2). Following sandbar formation, lagoon volume increased and there was an inland transition to lentic conditions between rkms 0 and 0.72 .

The second environmental phase lasted 27 days (13 July-8 August; Fig. 3) and was characterized by intense warming and stratification. Abiotic conditions during phase 2 were driven by wave overtopping events on 13-14 July and 25 July that delivered large amounts of seawater to the lagoon. Seawater inputs increased lagoon water volume and the upstream extent of lagoon inundation by $117 \mathrm{~m}$ (to rkm 0.83 ), where it remained for the duration of the study. The water column was vertically stratified across all three lagoon sample reaches, with relatively cool and well-oxygenated freshwater in the upper water column and warm saline water at depths $\geq 1.1 \mathrm{~m}$ (Fig. 4d-f). DTS revealed progressive warming of the salt water at the bottom of the lagoon during phase 2 (Fig. 3), and both the instantaneous maximum daily temperature and the MWMT in each sample reach were observed during this period (Fig. 5).

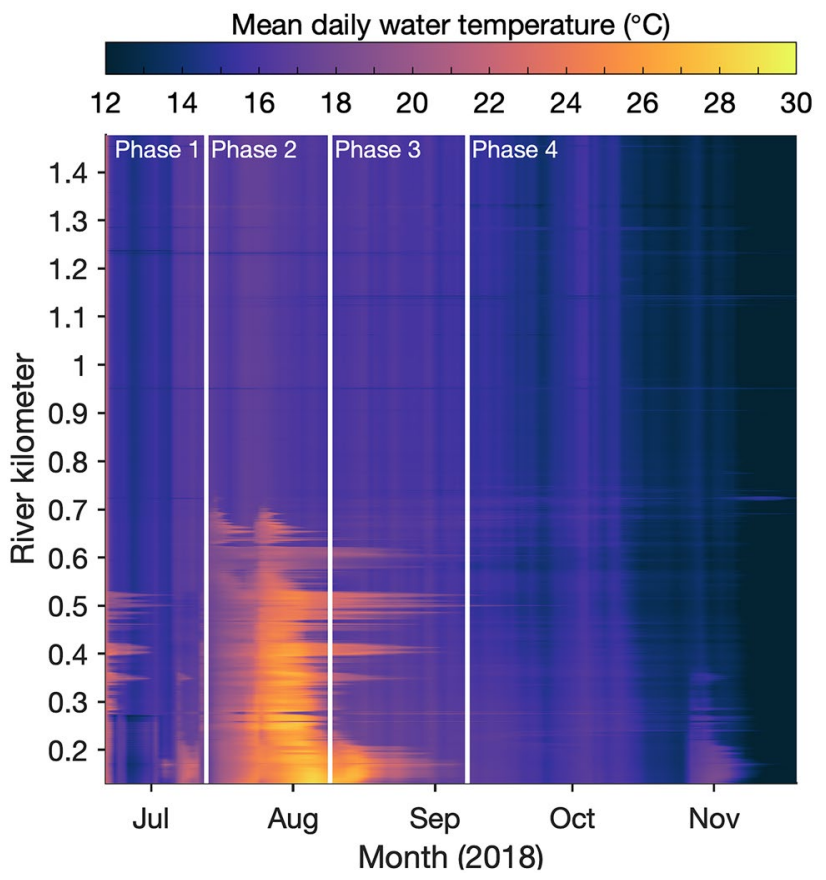

Fig. 3 Mean daily water temperature profile in the Scott Creek (CA, USA) estuary/lagoon and lower mainstem creek between 21 June and 20 November 2018 determined using distributed temperature sensing technology. The direction of streamflow is from top to bottom ( $y$-axis) and time is from left to right ( $x$-axis). Environmental phases were 20 June-12 July (phase 1), 13 July-8 August (phase 2), 9 August-7 September (phase 3), and 8 September-20 November (phase 4) 2018. River kilometer is distance upstream from the California State Route 1 bridge 
Fig. 4 Vertical profiles of temperature (left column), dissolved oxygen concentration (center column), and salinity (right column) collected in the Scott Creek (CA, USA) estuary/ lagoon during the 2018 dry season. Vertical profiling occurred on 28-29 June (phase 1), 2-3 August (phase 2), 4 September (phase 3), 9 October (early phase 4), and 1 November (late phase 4). Measurements for each parameter were collected at irregularly spaced sampling transects (see Methods: "Water Quality") and values were interpolated between transects. River kilometer is distance upstream from the California State Route 1 bridge
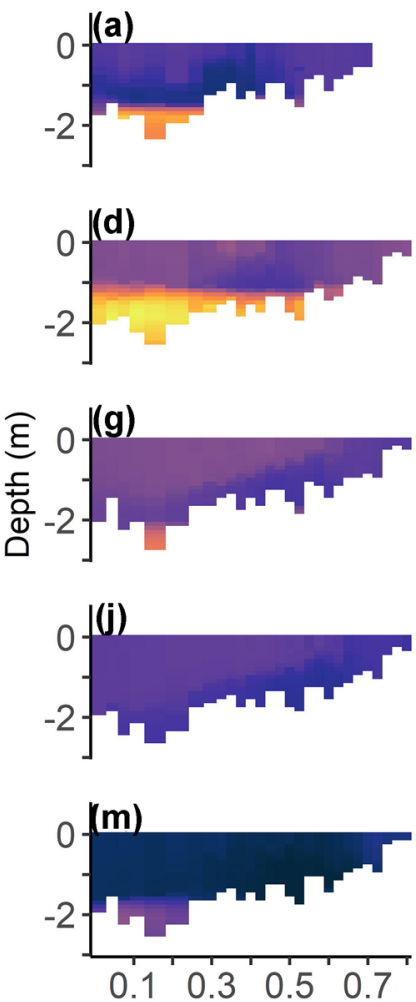

Temperature $\left({ }^{\circ} \mathrm{C}\right)$

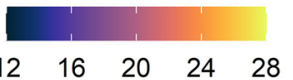

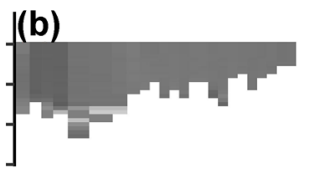

(e)
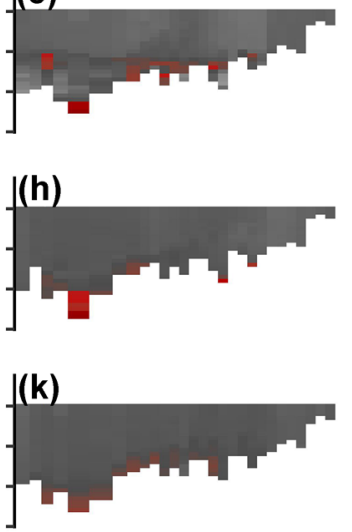

(n)
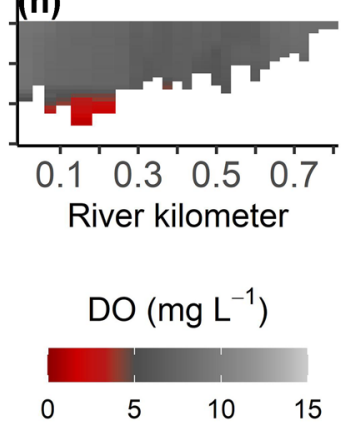
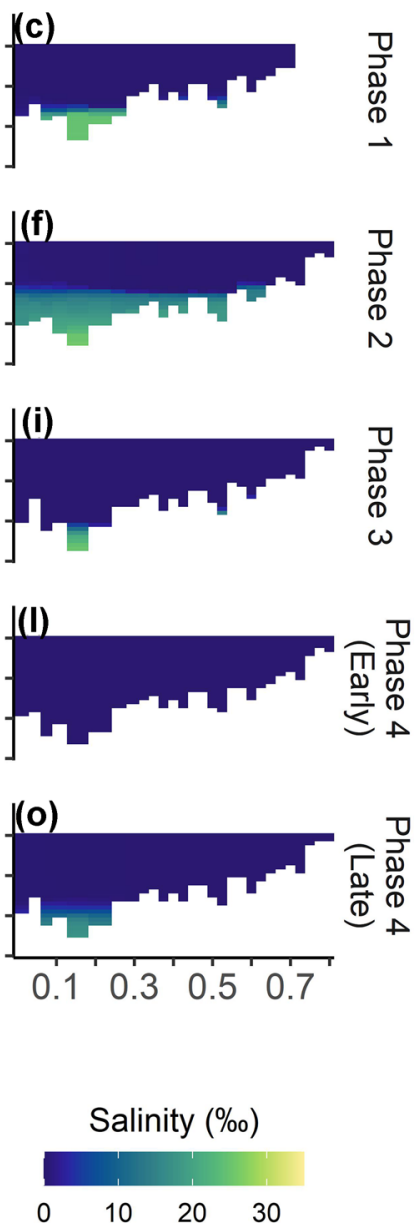

By 9 August, continual seepage of trapped saltwater through the sandbar (driven by a pressure differential between the lagoon and the Pacific Ocean) was sufficient to break down the strong vertical density differences that maintained stratification of the water column. This marked the onset of phase 3 (9 August-7 September, 30 days) and allowed wind-driven vertical mixing to freshen and cool nearly the entire water column (Table 2). While DTS data indicated persistent pockets of warm saltwater during this environmental phase (horizontal bands of warm temperature in Fig. 3), these pockets were relatively small and generally restricted to the deepest locations in the lagoon (depths $>2.0$ m; Fig. 4g-i).

By 8 September, warm saline water was largely absent from the lagoon for the first time since sandbar formation on 5 July ( 65 days earlier). This marked the beginning of phase 4 (8 September-20 November), a protracted 74-day period of cooling aided by progressively shorter photoperiod, cooler weather conditions, and frequent wind-driven mixing of the water column. During this final environmental phase, there was a steady transition to relatively homogeneous thermal conditions throughout the study segment (Figs. 3 and $4 \mathrm{j}-1)$. A period of wave overtopping during late phase 4
(24 October) delivered modest amounts of saltwater to the lagoon (Fig. 3) and a single pocket of saline and hypoxic water accumulated at depths $>1.7 \mathrm{~m}$ in the lower and middle lagoon sample reaches (rkm 0.07-0.20). Nevertheless, the vast majority of the lagoon remained fresh, well-oxygenated, and cool (Fig. 4m-o, Table 2).

\section{Steelhead Abundance, Growth, and Condition Factor}

We PIT-tagged 1,475 juvenile steelhead across the five monthly seining events and captured an additional 455 individuals in the lagoon that were tagged (by us) prior to this study. Approximately 44\% $(n=843)$ of these fish were captured on two or more sampling occasions resulting in 5,163 total captures of PIT-tagged individuals. An additional 6,022 juveniles $\geq 65 \mathrm{~mm}$ FL ( $53.8 \%$ of the total captures) were captured and subsequently released without receiving a PIT tag. Capture histories from PIT-tagged individuals were used to construct four POPAN models. Before ranking candidate models, we performed a $\chi^{2}$ goodness-of-fit test which indicated a modest lack of model fit $\left(\chi^{2}=69.54\right.$, $d f=39, p=0.0019)$; therefore, a variance inflation factor $(\widehat{c}$ 
Table 2 Vertical profile means and ranges ( $\min =$ minimum, $\max =$ maximum) for water temperature, dissolved oxygen concentration, and salinity by sample reach during each environmental phase

\begin{tabular}{|c|c|c|c|c|c|c|c|c|c|c|c|}
\hline \multirow[t]{2}{*}{ Period } & \multirow[t]{2}{*}{ Profile date(s) } & \multirow[t]{2}{*}{ Sample reach } & \multicolumn{3}{|c|}{ Temperature $\left({ }^{\circ} \mathrm{C}\right)$} & \multicolumn{3}{|c|}{$\begin{array}{l}\text { Dissolved oxygen } \\
\left(\mathrm{mg} \mathrm{L}^{-1}\right)\end{array}$} & \multicolumn{3}{|c|}{ Salinity (\%o) } \\
\hline & & & Mean & Min & Max & Mean & Min & Max & Mean & Min & Max \\
\hline \multirow[t]{4}{*}{ Phase 1 (20 Jun-12 Jul) } & \multirow[t]{4}{*}{ 28-29 Jun } & Lower lagoon & 16.6 & 14.2 & 26.2 & 8.7 & 6.8 & 18.1 & 3.04 & 0.15 & 24.77 \\
\hline & & Middle lagoon & 15.2 & 13.9 & 24.9 & 9.6 & 8.6 & 18.4 & 1.19 & 0.12 & 24.75 \\
\hline & & Upper lagoon & 15.9 & 14.8 & 18.5 & 9.1 & 7.5 & 10.3 & 0.50 & 0.11 & 16.10 \\
\hline & & Riverine $^{\mathrm{a}}$ & 16.2 & 14.0 & 17.3 & -- & -- & -- & $<0.1$ & -- & -- \\
\hline \multirow[t]{4}{*}{ Phase 2 (13 Jul-8 Aug) } & \multirow[t]{4}{*}{ 2-3 Aug } & Lower lagoon & 21.6 & 17.8 & 27.8 & 6.9 & 0.3 & 11.3 & 7.75 & 0.43 & 25.71 \\
\hline & & Middle lagoon & 19.0 & 15.6 & 27.3 & 6.6 & 3.0 & 10.7 & 3.96 & 0.15 & 19.77 \\
\hline & & Upper lagoon & 17.8 & 15.6 & 24.9 & 7.5 & 3.3 & 12.0 & 2.09 & 0.12 & 18.16 \\
\hline & & Riverine $^{a}$ & 17.7 & 15.0 & 20.0 & -- & -- & -- & $<0.1$ & -- & -- \\
\hline \multirow[t]{4}{*}{ Phase 3 (9 Aug-7 Sept) } & \multirow[t]{4}{*}{4 Sept } & Lower lagoon & 17.7 & 16.6 & 22.6 & 5.8 & 0.3 & 6.8 & 1.35 & 0.16 & 25.28 \\
\hline & & Middle lagoon & 17.3 & 15.5 & 18.3 & 6.1 & 4.3 & 7.0 & 0.19 & 0.15 & 2.54 \\
\hline & & Upper lagoon & 16.4 & 15.4 & 17.9 & 6.8 & 1.1 & 7.9 & 0.29 & 0.14 & 13.99 \\
\hline & & Riverine $^{\mathrm{a}}$ & 16.2 & 14.8 & 18.3 & -- & -- & - & $<0.1$ & -- & -- \\
\hline \multirow[t]{4}{*}{ Phase 4 Early ( 8 Sept-24 Oct) } & \multirow[t]{4}{*}{9 Oct } & Lower lagoon & 16.1 & 15.4 & 16.4 & 6.0 & 4.1 & 7.3 & 0.16 & 0.15 & 0.26 \\
\hline & & Middle lagoon & 16.0 & 14.8 & 16.5 & 5.8 & 4.4 & 7.1 & 0.16 & 0.15 & 0.17 \\
\hline & & Upper lagoon & 15.3 & 14.6 & 16.4 & 5.9 & 4.4 & 6.9 & 0.15 & 0.14 & 0.16 \\
\hline & & Riverine $^{a}$ & 15.3 & 14.5 & 17.7 & -- & -- & -- & $<0.1$ & -- & -- \\
\hline \multirow[t]{4}{*}{ Phase 4 Late (25 Oct-20 Nov) } & \multirow[t]{4}{*}{$1 \mathrm{Nov}$} & Lower lagoon & 14.1 & 13.1 & 18.5 & 7.4 & 1.2 & 8.9 & 2.02 & 0.26 & 17.49 \\
\hline & & Middle lagoon & 13.1 & 12.4 & 16.9 & 6.8 & 1.8 & 7.6 & 0.53 & 0.16 & 14.17 \\
\hline & & Upper lagoon & 13.0 & 12.3 & 14.3 & 7.1 & 5.8 & 8.4 & 0.16 & 0.16 & 0.17 \\
\hline & & Riverine $^{\mathrm{a}}$ & 13.4 & 12.5 & 14.5 & -- & -- & - & $<0.1$ & -- & - \\
\hline
\end{tabular}

${ }^{a}$ Vertical profile data were not collected in the riverine sample reach. riverine water temperature was derived from DTS measurements collected during the same periods that vertical profiling occurred

$=1.78)$ was applied to the model set to correct for overdispersion. The top POPAN model had the lowest QAIC $_{c}$ score, received $99.9 \%$ of the model weight, and had timedependent probabilities of survival, capture, and entry $((\phi$ $\left.{ }_{(t)} p_{(t)} \beta_{(t)} N^{*}\right)$; Table 3).

An estimated 2,183 (95\% CI =2,010-2,371) juvenile steelhead were present in the estuary just before sandbar formation in early July, and the abundance of lagoonrearing steelhead increased over the next two months, reaching a high of $3,065(95 \% \mathrm{CI}=2,857-3,289)$ individuals in early September (Fig. 6a). Following this peak, there was an abrupt 34\% decline in steelhead abundance in October $\left(N_{\text {Oct }}=2,017 ; 95 \% \mathrm{CI}=1,830-2,223\right)$ and the population remained at approximately this level for the remainder of the study (Fig. 6a). We found differences in both steelhead MSGR (ANOVA, $F_{4,1755}=283, p<0.001$; Fig. $6 \mathrm{~b}$ ) and condition factor (ANOVA, $F_{4,5067}=167$, $p<0.001$; Fig. 6c) across the five monthly sample events. Mean steelhead growth rates were positive during every month of the study (Fig. 6b) and there was a stepwise monthly increase in mean fork length (Electronic Supplemental Material \#1, Fig. S1). Although temporal patterns differed somewhat for steelhead growth rate versus condition factor, the lowest mean monthly values for each metric occurred in October for MSGR $\left(0.52 \pm 0.03 \% \mathrm{~g}^{-1}\right.$ day $^{-1}$; Fig. 6b), and in October and November for condition factor $(K=1.06 \pm 0.01$ both months; Fig. $6 c)$.

\section{Movement Behavior of PIT-Tagged Individuals}

After removing fish milling behavior, a total of 17,797 distinct movement events were generated by 1,572 PIT-tagged juvenile steelhead across the study period. Most (93.9\%) fish movement occurred at the Lagoon Array $(n=16,716$ events generated by 1,521 different individuals). Markedly fewer steelhead were detected moving past the Interface Array $(5.5 \% ; n=983$ events produced by 412 individuals) or the Riverine Array $(0.6 \% ; n=98$ events generated by 40 individuals), and the bulk of detections at these two stations occurred during the last five days of the study (Electronic Supplemental Material \#2, Fig. S2). Although daily operational status was variable at each station, overall estimates of antenna efficiency across the study period were $99.4 \%$ and $88.3 \%$ at the Interface and Riverine arrays, respectively. We were unable to derive a comparable estimate of antenna efficiency at the Lagoon Array 
Fig. 5 Seven-day moving average of daily maximum water temperatures measured in each sample reach (Scott Creek, CA, USA), during the study period. The maximum value in each time series represents the maximum weekly maximum temperature (MWMT). The dates (2018) of MWMT in each sample reach were 3 August in the lower lagoon, 30 July in the middle lagoon, and 27 July in both the upper lagoon and riverine sample reaches

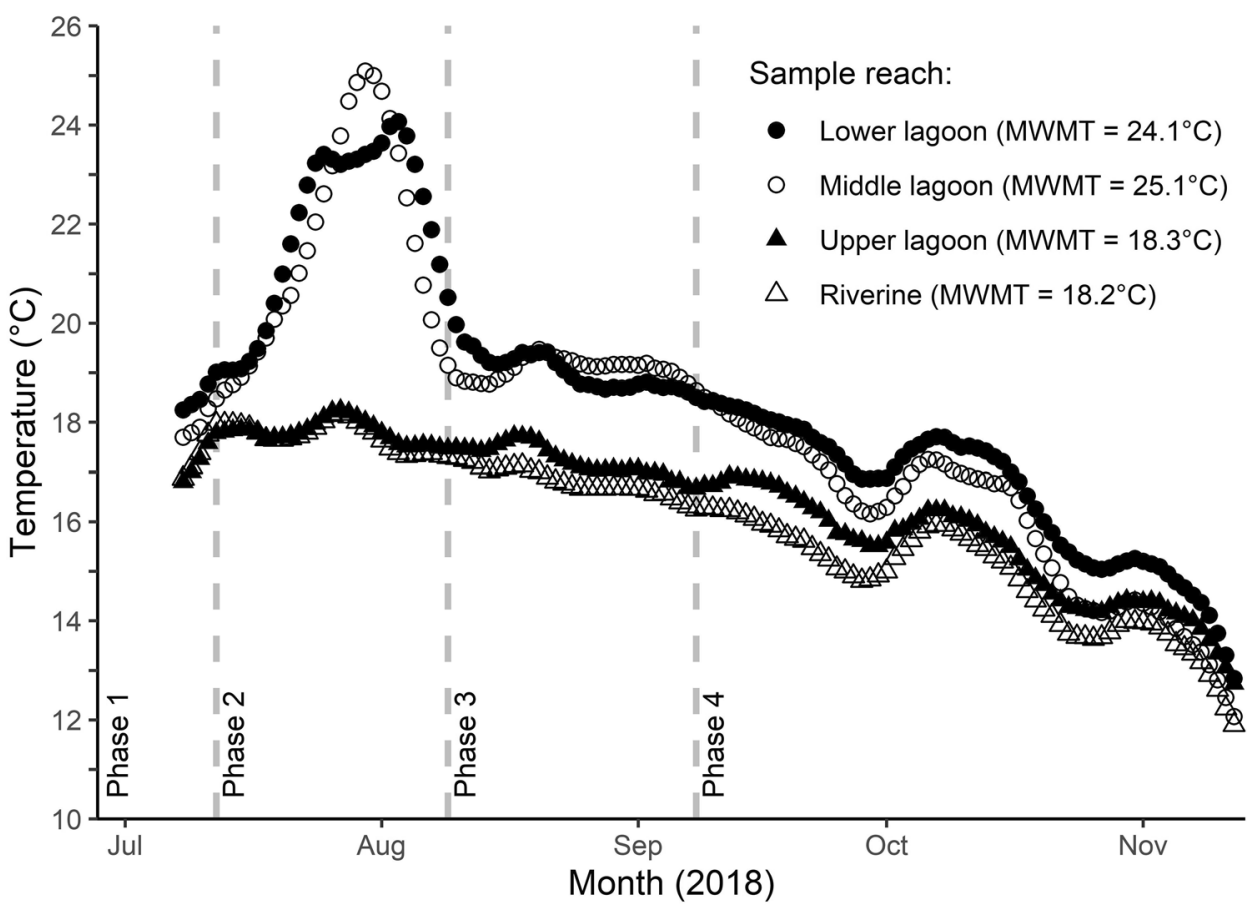

(see Electronic Supplemental Material \#2, Table S1). It is instructive to note that $81.5 \%$ of the 1,930 PIT-tagged juvenile steelhead captured in the lagoon during fish sampling were subsequently detected at one or more antenna arrays during the study period.

Unambiguous upstream or downstream directionality was assigned to $25.8 \%(n=4,595)$ of all fish movement

Table 3 Comparison of four candidate POPAN models used to estimate the probability of survival $(\phi)$, probability of capture $(p)$, probability of entry $(\beta)$, and super-population size $\left(N^{*}\right)$ for juvenile steelhead in the Scott Creek (CA, USA) lagoon

\begin{tabular}{lccc}
\hline Model $^{\mathrm{a}, \mathrm{b}, \mathrm{c}}$ & $\mathrm{QAIC}_{\mathrm{c}}$ & $\Delta$ QAIC $_{\mathrm{c}}$ & Model weight \\
\hline$\phi_{(t)} p_{(t)} \beta_{(t)} N^{*}$ & 6707.92 & 0.00 & 0.999 \\
$\phi_{(.)} p_{(t)} \beta_{(t)} N^{*}$ & 6727.26 & 19.34 & $<0.001$ \\
$\phi_{(t)} p_{(.)} \beta_{(t)} N^{*}$ & 7170.91 & 462.99 & 0.000 \\
$\phi_{(.)} p_{(.)} \beta_{(t)} N^{*}$ & 7409.83 & 701.91 & 0.000 \\
\hline
\end{tabular}

${ }^{\mathrm{a}} \mathrm{A}$ variance inflation factor $(\hat{c}=1.78)$ was applied to the model set to correct for overdispersion

${ }^{\mathrm{b}}$ Key to model subscripts: $(t)=$ parameter varied with time; and $()=$. parameter was estimated as the mean value and was held constant over time

${ }^{\mathrm{c}}$ Super-population size $\left(N^{*}\right)$ is included in the model notion by convention. However, the super-population estimate was potentially biased due to our sampling protocols (i.e., multiple captures of untagged fish; see Methods: "Steelhead Abundance, Growth, and Condition Factor") and not reported herein events; again the majority of which occurred at the Lagoon Array $(n=4,021,87.5 \%$; Fig. S2). Statistical inference was restricted to juvenile steelhead movement data generated at the Lagoon Array due to a highly skewed temporal distribution of movement events at the Interface array and inadequate sample size (too few events) at the Riverine Array. Directional movement at the Lagoon Array was non-uniformly distributed throughout a 24-h period (Hermans-Rasson test, $T_{\text {Downstream }}=1251.8, p<0.001 ; T_{\text {Upstream }}=1348.5, p<0.001$ ) with most directional movement occurring during crepuscular periods. We compared mean directional movements within the four environmental phases and further partitioned phase 4 into early and late periods due to the protracted length of this environmental phase (see Results: "Spatiotemporal Variability in Abiotic Conditions"). The mean time of day for upstream and downstream movement by PIT-tagged steelhead differed within each environmental phase (Mardia-WatsonWheeler test, $p<0.001$ in all cases) except during phase 2 $(p=0.426)$. Specifically, a peak in downstream movement events (i.e., fish moving into the lower lagoon) occurred at dusk $(40.2 \%, n=777)$, whereas a peak in upstream movement events (i.e., moving inland from the lower lagoon) occurred at dawn (46.2\%, $n=966$; Fig. 7). Although the movement patterns exhibited by individual steelhead were highly variable, our results suggested a broad pattern in which lagoon-rearing steelhead often retreated from the lower lagoon at dawn, resided between the Lagoon and Interface Arrays ( $400 \mathrm{~m}$ 


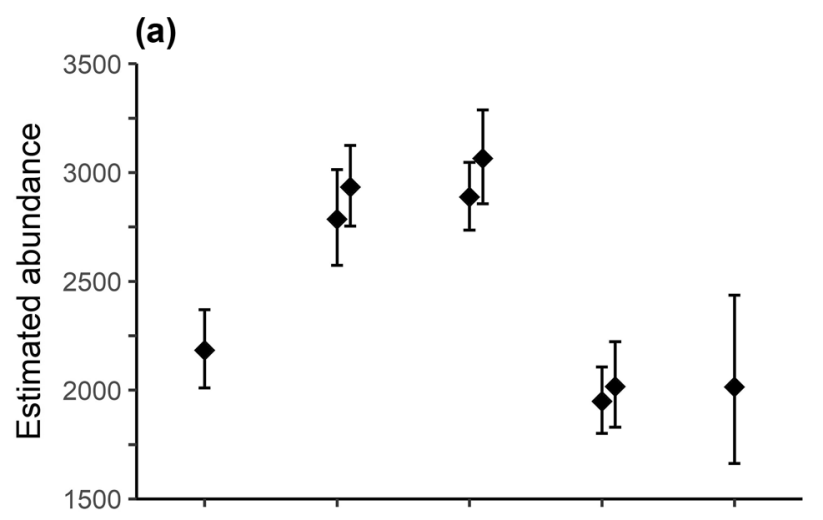

(b)

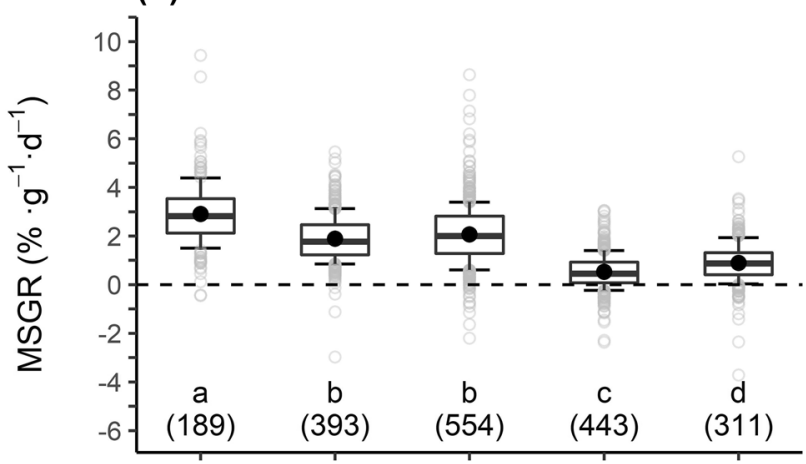

(c)

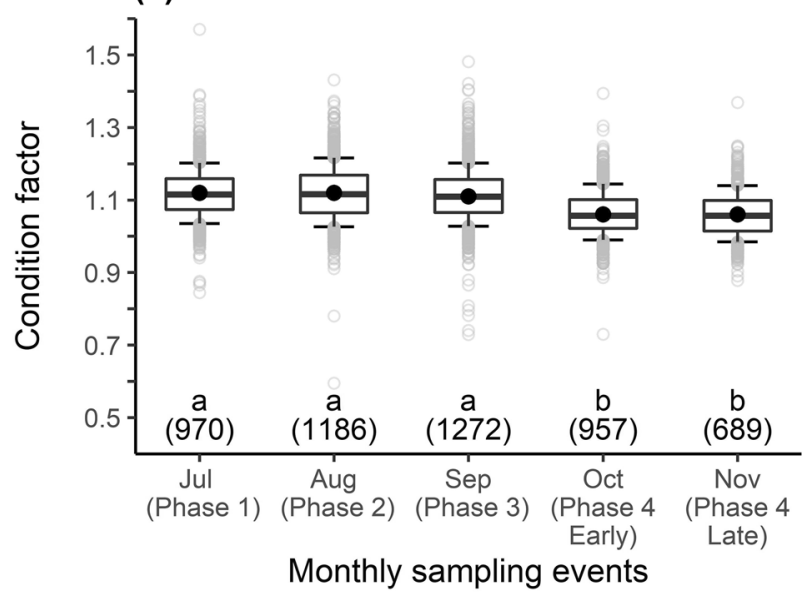

Fig. 6 Estimated (a) abundance, (b) mass-specific growth rate (MSGR), and (c) condition factor of juvenile steelhead in the Scott Creek (CA, USA) estuary/lagoon during each monthly sample event (July-November 2018). For panel (a), abundance point estimates (diamonds) reflect the best-approximating POPAN model and are shown with 95\% confidence intervals. In panels (b) and (c), each box denotes the 25 th and 75 th percentiles with the median value shown as a horizontal line. The whiskers denote the 10th and 90th percentiles and outliers appear as open circles. The mean value is represented by a solid circle. Parenthetical numbers indicate sample sizes. Different lowercase letters denote significant differences between sampling events (ANOVA followed by Tukey's HSD test)

distance) during the day, and returned to the lower lagoon around sunset regardless of environmental phase.

\section{Discussion}

\section{Persistent Stratification and Reduced Habitat Suitability}

Seawater delivered during episodic wave overwash events strongly influenced ecological conditions in the shallow (max. depth $=2.8 \mathrm{~m})$ Scott Creek lagoon during much of our 154-day study. High-resolution DTS and vertical profile measurements identified multiple inputs of seawater following sandbar formation that resulted in haline stratification and facilitated the development of distinct vertical gradients in water temperature and DO concentration across much of the lagoon (Figs. 3 and 4). Strong stratification inhibited wind-driven mixing of the water column and allowed warm and hypoxic conditions to persist within the lower water column, particularly at the deepest points of the lagoon (Fig. 4). We documented an extensive lower saline layer extending inland to rkm 0.7 which persisted in some (deep) locations for up to 65 days (Figs. 3 and 4).

A large literature on the temperature preferences and requirements of juvenile $O$. mykiss suggests that growth is optimized between 14 and $19{ }^{\circ} \mathrm{C}$ depending on food availability (Hokanson et al. 1977; Hicks 2000; Richter and Kolmes 2005), and that temperatures above 22-24 ${ }^{\circ} \mathrm{C}$ induce cellular stress (e.g., production of heat shock proteins; Viant et al. 2003; Werner et al. 2005), alter fish behavior (e.g., reduce agonistic and foraging activity; Sloat and Osterback 2013), and reduce various proxy measures of fitness (e.g., growth, body size, and lipid storage; Kammerer and Heppell 2013). Consequently, elevated water temperatures $\left(\geq 21^{\circ} \mathrm{C}\right)$ generally elicit thermoregulatory strategies in steelhead-principally emigration to cool-water refuges when such habitats are available (Nielsen et al. 1994; Ebersole et al. 2001; Baird and Krueger 2003). Additionally, juvenile steelhead are sensitive to low DO concentration $\left(<5.0 \mathrm{mg} \mathrm{L}^{-1}\right.$; Carter 2005 ) and have limited salinity tolerance (osmoregulatory ability) prior to the parr-smolt transformation (Boughton et al. 2017). Hence, the presence of warm saline water at the bottom of the Scott Creek lagoon during the first half ( $\sim 80$ days) of the study period reduced the amount of suitable freshwater habitat for juvenile steelhead to varying degrees. At its most extreme during midsummer (e.g., 13 July-8 August, phase 2), strong vertical stratification and heating likely restricted juvenile steelhead to the top $\sim 1.0 \mathrm{~m}$ of the water column and reduced the volume of suitable lagoon habitat by approximately $40 \%$ relative to unstratified conditions in autumn (after 8 September, phase 4; Fig. 4). However, thermal conditions were likewise periodically stressful in the upper water 
Fig. 7 Histograms of directional movement detected at the Scott Creek (CA, USA) Lagoon PIT tag antenna array (Lagoon Array) relative to sunrise (left panels) and sunset (right panels) during each environmental phase (panel rows). Blue bars denote upstream movement and orange bars denote downstream movement (bin width $=0.25 \mathrm{~h}$ ). Dark background shading in each panel denotes nighttime, light shading indicates dawn or dusk, and the unshaded region represents daylight hours. Environmental phase dates (2018) were 20 June-12 July (phase 1), 13 July-8 August (phase 2), 9 August-7 September (phase 3), and 8 September-20 November (phase 4)
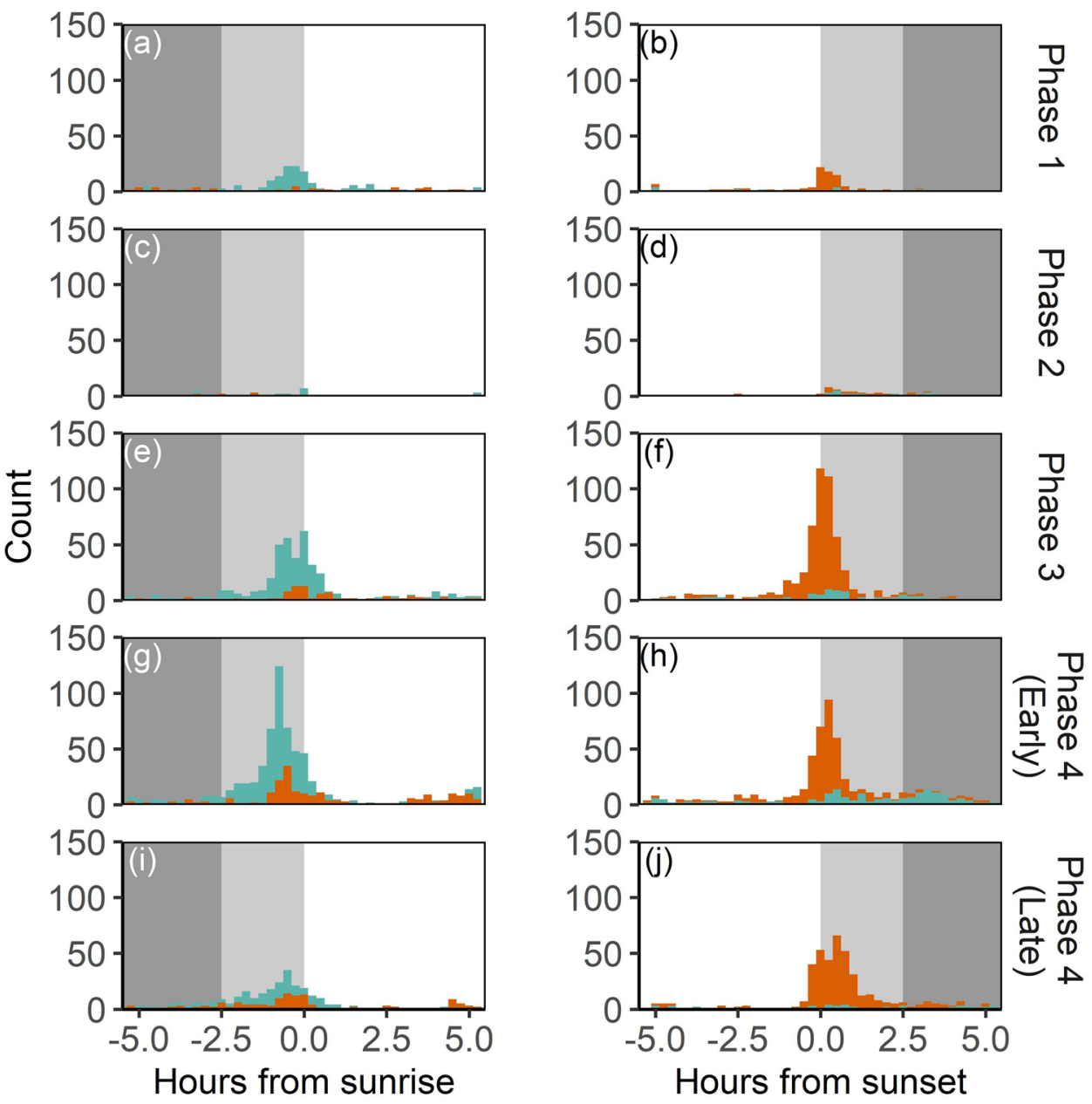

Upstream Downstream

column during stratification (temperatures reaching 21.0 ${ }^{\circ} \mathrm{C}$ ) with potential negative physiological and ecological consequences (Smith 1990; Sullivan et al. 2000; Werner et al. 2005) for lagoon-rearing individuals.

\section{Steelhead Abundance and Performance}

Despite highly dynamic abiotic conditions and periods of diminished habitat suitability, juvenile steelhead benefited from lagoon rearing as evidenced by high abundance, positive growth, and robust condition factors. Our monthly mark-recapture seining events revealed a temporal pattern of steelhead recruitment to the lagoon during phases 1 and 2 (July and August), peak abundance during phases 2 and 3 (August and September), and then a decrease in abundance, mean mass-specific growth rate, and mean condition factor during phase 4 (October and November; Fig. 6). Interestingly, high juvenile steelhead abundance and growth rates were observed during phase 2 despite strong stratification gradients and a substantial reduction in favorable freshwater rearing habitat-conditions that would be expected to limit fish growth via increased per capita competition (Gregory and Wood 1999; Keeley 2001) and bioenergetic stress (Boughton et al. 2017).

Bioenergetics studies have shown that the net effect of elevated water temperature on juvenile salmonid growth is dependent upon food consumption rates (Boughton et al. 2007; Myrvold and Kennedy 2015; although see Viant et al. 2003) and the variability in metabolic costs associated with accessing habitats with abundant prey (Armstrong et al. 2013; Brewitt et al. 2017). While we did not quantify temporal changes in prey availability or consumption rates by lagoon-rearing steelhead, community and food habit investigations conducted in nearby Pescadero Creek estuary/lagoon (San Mateo County, CA, USA) demonstrated that both invertebrate density and richness (Robinson 1993) and juvenile steelhead stomach fullness (Martin 1995) were high in the lower lagoon following sandbar 
formation and subsequently declined following stratification of the water column. We propose that high rates of secondary production in the Scott Creek lagoon during summer (phases 1 and 2) may have helped mitigate the negative effects of high water temperature on steelhead growth in the short term, as recently demonstrated for juvenile coho salmon rearing in a northern California river (Lusardi et al. 2020).

\section{Oversummer Lagoon Fidelity}

Spatiotemporal patterns of movement and habitat use by juvenile steelhead in coastal California watersheds are thought to be driven by dynamic trade-offs between water quality, resource availability, and predation risk (Satterthwaite et al. 2012). Based on previous research in the Scott Creek estuary/ lagoon (e.g., Bond et al. 2007; Hayes et al. 2011; Osterback et al. 2018), we expected juvenile steelhead would attempt to exploit abundant trophic resources in the lower lagoon and retreat upstream to riverine habitat when abiotic conditions became physiologically stressful. While we documented substantial movement of PIT-tagged steelhead in and out of the lower lagoon (relative to the Lagoon Array at rkm 0.3), consistent with the findings of Osterback et al. (2018), the vast majority of fish moving upstream during our study ultimately took refuge in the middle or upper lagoon sample reaches (Fig. S2). Contrary to previous reports, few fish were detected moving beyond the lagoon-riverine Interface Array (rkm 0.7) during our study until late in phase 4 immediately prior to the onset of the first rainfall event (Fig. S2). Our results highlight that interannual variability in hydrology and lagoon physiochemistry may result in different patterns of fish behavior and habitat use.

Notably, while our study was conducted during a "below normal" water year in California (https://cdec.water.ca. gov/reportapp/javareports?name $=$ WSIHIST, last accessed 1 October 2021), the Scott Creek lagoon maintained considerable volume during the dry season and lentic/lagoonal conditions existed upstream to rkm 0.83 . High sandbar elevation and adequate freshwater inflow substantially increased the amount of potential salmonid rearing habitat relative to previous low water years (e.g., water year 2015; Osterback et al. 2018), especially in the upper lagoon sample reachan area characterized by comparatively high habitat complexity (Fig. 2) and available cover from avian predators (Frechette et al. 2016). Importantly, water quality parameters in the upper lagoon sample reach were often similar to conditions in the adjacent mainstem riverine sample reach during the study period, particularly at the head of the lagoon where $117 \mathrm{~m}$ of lentic habitat was unaffected by saltwater intrusion (due to streambed elevation) or vertical stratification (Figs. 3 and 4). Maximum weekly maximum temperature in the upper lagoon sample reach was $18.3{ }^{\circ} \mathrm{C}$, nearly
$6{ }^{\circ} \mathrm{C}$ lower than MWMT values in the lower and middle lagoon sample reaches (Fig. 5), and well below the $20.5{ }^{\circ} \mathrm{C}$ upper threshold recommended by Sullivan et al. (2000) to protect juvenile steelhead rearing. Thus, a portion of the upper lagoon potentially served as a critical cool-water refuge (Quiñones and Mulligan 2005; Torgersen et al. 2012) and provided opportunities for juvenile steelhead to behaviorally thermoregulate when water temperatures in the lower lagoon were unfavorable.

Few PIT-tagged juvenile steelhead were detected crossing the lagoon-riverine interface (i.e., emigrating from the lagoon) during our 154-day investigation until 15 November, whereupon there was a salient spike in inland movement during the final five days of the study (27 PIT-tagged emigrants in phases 1-3 combined versus 389 during phase 4; Fig. S2b). A retreat by lagoon-rearing steelhead to riverine habitat has been reported elsewhere (Shapovalov and Taft 1954; Hayes et al. 2011; Osterback et al. 2018) and attributed to lagoon water quality degradation late in the dry season (Hayes et al. 2011). However, poor water quality was clearly not the driver of emigration from the lagoon during our study, as there was a return to favorable abiotic conditions throughout the study segment during phase 4 (Figs. 3 and $4 \mathrm{j}-\mathrm{O}$; Table 2), well before the spike in upstream movement occurred. Instead, upstream movement appeared to be associated with a major shift in weather (i.e., onset of winter precipitation), and more closely aligns with the proposition by Huber and Carlson (2020) that emigration may be prompted by cold water temperatures and shorter photoperiod.

\section{Diel Patterns of Fish Movement}

Although juvenile steelhead were active in the lagoon throughout the day, there were marked peaks in upstream and downstream movement by PIT-tagged individuals concurrent with changing light conditions at dawn and dusk, respectively (Fig. 7). Juvenile salmonids are known to exhibit highly plastic movement behavior, shifting activity between diurnal, nocturnal, and crepuscular periods in response to foraging opportunities and perceived predation risk (Hyatt 1980; Watson et al. 2019). In the Scott Creek lagoon, the benthic and epibenthic invertebrates that support salmonid growth and production (primarily amphipods, isopods, and mysids) are disproportionately concentrated in the open water habitat of the lower lagoon (J. Kiernan, unpublished data). However, cover is scarce in the lower lagoon (Fig. 2a) and avian predation on juvenile salmonids in this reach is known to be high (Frechette et al. 2013; Osterback et al. 2014). Hence, crepuscular movement by juvenile steelhead is presumably a behavioral mechanism to increase feeding success while minimizing mortality risk, a behavior exhibited by lakerearing juvenile sockeye salmon (Oncorhynchus nerka, Clark and Levy 1988; Scheuerell and Schindler 2003). Moreover, 
since many lentic invertebrates exhibit diel vertical migrations, ascending at dusk and descending at dawn (Haney 1988; Hays 2003), steelhead movement into the prey-rich lower lagoon at dusk and subsequent retreat at dawn may help synchronize steelhead foraging activities with spatiotemporal patterns in prey availability. It should be noted that the Scott Creek estuary/lagoon is a relatively simple ecosystem with a depauperate fish assemblage in which $O$. mykiss are the apex aquatic predator. In more ecologically and structurally complex estuaries/lagoons, juvenile steelhead movement may differ from the patterns we observed due to different predator-prey dynamics.

\section{The Autumn Population Paradox}

Following robust steelhead abundance, growth, and condition factor in late summer (phase 3, September), all fish performance metrics examined in this study decreased during autumn (phase 4, October and November) when abiotic conditions were purportedly more favorable, particularly water temperature (Figs. 3 and 6). Declining fish abundance following lagoon cooling is an emerging pattern that has been observed in previous studies of Scott Creek and periodically in other central California lagoons (e.g., Pescadero Creek; J. Jankovitz, personal communication). However, the mechanism(s) behind such declines are not well understood and likely vary between systems and among years. During our study, the Interface Array provided evidence that very few PIT-tagged fish emigrated from the lagoon, even when water temperatures were at a maximum. Therefore, densitydependent processes and (or) latent stress responses likely explain in part the declines in steelhead abundance and performance observed following destratification and cooling.

It is probable that strong vertical stratification during the summer chiefly confined juvenile steelhead to the upper water column, and that the corresponding reduction in habitat increased both intraspecific competition (Gregory and Wood 1999; Keeley 2001) and predation risk (Frechette et al. 2013; Osterback et al. 2014). Alternatively, some individuals may have retreated to the middle or upper lagoon and were not captured during subsequent mark-recapture sampling events in October and November. The decreases in juvenile steelhead growth rate and condition factor observed for fish captured in the lower lagoon during phase 4 may be latent consequences of sub-lethal thermal stress and (or) hypoxia experienced during the warm summer months. Abiotic conditions similar to those documented during our study have been shown to adversely affect juvenile $O$. mykiss metabolic rate and growth conversion efficiency (Werner et al. 2005; Feldhaus et al. 2010). It is also plausible that trophic processes constrained fish growth and condition, as negative bottom-up food web effects have been reported following destratification due to lingering DO impairment and reduced primary and secondary productivity (Smith 1990; Robinson 1993). Future study is warranted to assess the generality of autumn salmonid population declines in coastal lagoons and the ecological mechanisms underlying this phenomenon.

\section{Conclusions}

Bar-built estuaries are the dominant estuary type in many regions of the world (Perissinotto et al. 2010; McSweeney et al. 2017). These habitats often provide unique ecological services and are particularly important as nursery areas for estuarine-resident and freshwater fish species. Unfortunately, the productivity and resiliency of many estuaries and lagoons have been reduced by intensive habitat alteration and management (Heady et al. 2015), and these habitats may be especially vulnerable to climate change (Huang et al. 2020). In coastal California, there is growing evidence that extreme climatic events are becoming increasingly commonplace, altering the annual timing and duration of lagoon formation (i.e., sandbar open/close dynamics) and diminishing the quality of lagoon rearing habitat for imperiled juvenile salmonids (Osterback et al. 2018; Huber and Carlson 2020). This study found that strong vertical stratification (high salinity, high water temperature, and hypoxia in the lower water column) during midsummer substantially reduced the total volume of suitable lagoon rearing habitat for juvenile steelhead. Oversummer persistence of steelhead was facilitated by a mosaic of vertical and longitudinal physicochemical conditions and the recurrent movement of fish into refuge areas when abiotic and (or) ecological conditions were unfavorable. Future work examining estuary/ lagoon trophic dynamics is needed to assess the degree to which enhanced food resources may allow fish to occupy and persist in habitats that are physiologically suboptimal, particularly with respect to water temperature.

Supplementary Information The online version contains supplementary material available at https://doi.org/10.1007/s12237-021-01019-9.

Acknowledgements We thank Livier Enciso, Angela Garelick, Lindsay Hansen, Keith Hanson, Katie Kobayashi, Karlee Liddy, Nate Mantua, Erick Sturm, and numerous Scott Creek interns for field support. We are grateful to Eric Danner for the use of DTS equipment. Christopher Kratt and Scott Tyler from the Center for Transformative Environmental Monitoring Programs provided helpful guidance on DTS deployment and materials. Arnold Ammann, David Boughton, E.J. Dick, Nate Mantua, and Thomas Williams provided helpful feedback during the writing and analysis of this manuscript. We are especially grateful for the time, effort, and constructive comments provided by two anonymous reviewers and the associate editor during the peer review process. Lastly, we thank California Polytechnic State University's Swanton Pacific Ranch for land access and their continued support of our research and monitoring programs. 
Funding Financial support was provided by the National Marine Fisheries Service and California Department of Fish and Wildlife's Fisheries Restoration Grant Program. Reference to trade names or manufacturers is for descriptive purposes only and does not imply US Government endorsement of commercial products.

Data Availability Data are available from the authors upon reasonable request.

\section{Declarations}

Conflict of Interest The authors declare no competing interests.

Open Access This article is licensed under a Creative Commons Attribution 4.0 International License, which permits use, sharing, adaptation, distribution and reproduction in any medium or format, as long as you give appropriate credit to the original author(s) and the source, provide a link to the Creative Commons licence, and indicate if changes were made. The images or other third party material in this article are included in the article's Creative Commons licence, unless indicated otherwise in a credit line to the material. If material is not included in the article's Creative Commons licence and your intended use is not permitted by statutory regulation or exceeds the permitted use, you will need to obtain permission directly from the copyright holder. To view a copy of this licence, visit http://creativecommons.org/licenses/by/4.0/.

\section{References}

Agostinelli, C., and U. Lund. 2017. R package "circular": Circular statistics (version 0.4-93). https://r-forge.r-project.org/projects/ circular/. Accessed 1 October 2021.

Armstrong, J.B., D.E. Schindler, C.P. Ruff, G.T. Brooks, K.E. Bentley, and C.E. Torgersen. 2013. Diel horizontal migration in streams: Juvenile fish exploit spatial heterogeneity in thermal and trophic resources. Ecology 94 (9): 2066-2075.

Baird, O.E., and C.C. Krueger. 2003. Behavioral thermoregulation of brook and rainbow trout: Comparison of summer habitat use in an Adirondack River New York. Transactions of the American Fisheries Society 132 (6): 1194-1206.

Batschelet, E. 1981. Circular statistics in biology. New York: Academic Press.

Behrens, D.K., F.A. Bombardelli, and J.L. Largier. 2016. Landward propagation of saline waters following closure of a bar-built estuary: Russian River (California USA). Estuaries and Coasts 39 (3): 621-638.

Behrens, D.K., F.A. Bombardelli, J.L. Largier, and E. Twohy. 2013. Episodic closure of the tidal inlet at the mouth of the Russian River-A small bar-built estuary in California. Geomorphology 189: 66-80.

Bond, M.H., C.V. Hanson, R. Baertsch, S.A. Hayes, and R.B. MacFarlane. 2007. A new low cost in-stream antenna system for tracking passive integrated transponder (PIT) tagged fish in small streams. Transactions of the American Fisheries Society 136 (3): 562-566.

Bond, M.H., S.A. Hayes, C.V. Hanson, and R.B. MacFarlane. 2008. Marine survival of steelhead (Oncorhynchus mykiss) enhanced by a seasonally closed estuary. Canadian Journal of Fisheries and Aquatic Sciences 65 (10): 2242-2252.

Bond, R.M., A.P. Stubblefield, and R.W. Van Kirk. 2015. Sensitivity of summer stream temperatures to climate variability and riparian reforestation strategies. Journal of Hydrology: Regional Studies 4: 267-279.

Boughton, D.A., M. Gibson, R. Yedor, and E. Kelley. 2007. Stream temperature and the potential growth and survival of juvenile
Oncorhynchus mykiss in a southern California creek. Freshwater Biology 52 (7): 1353-1364.

Boughton, D., J. Fuller, G. Horton, E. Larson, W. Matsubu, and C. Simenstad. 2017. Spatial structure of water-quality impacts and foraging opportunities for steelhead in the Russian River estuary: An energetics perspective. U.S. Dept. Commerce, NOAA Technical Memorandum. NOAA-TM-NMFS-SWFSC-569.

Brewitt, K.S., E.M. Danner, and J.W. Moore. 2017. Hot eats and cool creeks: Juvenile Pacific salmonids use mainstem prey while in thermal refuges. Canadian Journal of Fisheries and Aquatic Sciences 74 (10): 1588-1602.

Carter K. 2005. The effects of dissolved oxygen on steelhead trout, coho salmon, and Chinook salmon biology and function by life stage. California Regional Water Quality Control Board, North Coast Region, Santa Rosa, California. Available at https://pdfs. semanticscholar.org/f75d/8e52325eb618e8fa73fe04a28df34bbae8f2. pdf

Clark, C.W., and D.A. Levy. 1988. Diel vertical migrations by juvenile Sockeye salmon and the antipredation window. The American Naturalist 131 (2): 271-290.

Clark, R., and K. O'Connor. 2019. A systematic survey of bar-built estuaries along the California coast. Estuarine Coastal and Shelf Science 226: 106285.

Cooch, E., and G.C. White. 2021. Program MARK, a gentle introduction. http://www.phidot.org/software/mark/docs/book/. Accessed 1 Oct 2021.

Cowley, P.D., and A.K. Whitfield. 2001. Fish population size estimates from a small intermittently open estuary in South Africa based on mark-recapture techniques. Marine and Freshwater Research 52: 283-290.

Crozier, L.G., M.M. McClure, T. Beechie, S.J. Bograd, D.A. Boughton, M. Carr, T.D. Cooney, J.B. Dunham, C.M. Greene, M.A. Haltuch, E.L. Hazen, D.M. Holzer, D.D. Huff, R.C. Johnson, C.E. Jordan, I.C. Kaplan, S.T. Lindley, N.J. Mantua, P.B. Moyle, J.M. Myers, M.W. Nelson, B.C. Spence, L.A. Weitkamp, T.H. Williams, and E. Willis-Norton. 2019. Climate vulnerability assessment for Pacific salmon and steelhead in the California Current Large Marine Ecosystem. PLOS ONE 14 (7): e0217711.

Ebersole, J.L., W.J. Liss, and C.A. Frissell. 2001. Relationship between stream temperature, thermal refugia and rainbow trout Oncorhynchus mykiss abundance in arid-land streams in the northwestern United States. Ecology of Freshwater Fish 10 (1): 1-10.

Emmett, R., R. Lianso, J. Newton, R. Thom, M. Hornberger, C. Morgan, C. Levings, A. Copping, and P. Fishman. 2000. Geographic signatures of North American West Coast estuaries. Estuaries 23 (6): 765-792.

Feldhaus, J.W., S.A. Heppell, H. Li, and M.G. Mesa. 2010. A physiological approach to quantifying thermal habitat quality for Redband rainbow trout (Oncorhynchus mykiss gairdneri) in the south Fork John Day River Oregon. Environmental Biology of Fishes 87 (4): 277-290.

Frechette, D.M., A.L. Collins, J.T. Harvey, S.A. Hayes, D.D. Huff, A.W. Jones, N.A. Retford, A.E. Langford, J.W. Moore, A.-M.K. Osterback, W.H. Satterthwaite, and S.A. Shaffer. 2013. A bioenergetics approach to assessing potential impacts of avian predation on juvenile steelhead during freshwater rearing. North American Journal of Fisheries Management 33 (5): 1024-1038.

Frechette, D., W.H. Satterthwaite, A.-M.K. Osterback, and S.A. Hayes. 2016. Steelhead abundance in seasonally closed estuaries estimated using mark recapture methods. U.S. Dept. Commerce. NOAA Technical Memorandum NOAA-TM-NMFS-SWFSC-555.

Gregory, T.R., and C.M. Wood. 1999. Interactions between individual feeding behaviour, growth, and swimming performance in juvenile rainbow trout (Oncorhynchus mykiss) fed different rations. Canadian Journal of Fisheries and Aquatic Sciences 56 (3): 479-486. 
Haney, J.F. 1988. Diel patterns of zooplankton behavior. Bulletin of Marine Science 43 (3): 583-603.

Hausner, M.B., F. Suárez, K.E. Glander, N. van de Giesen, J.S. Selker, and S.W. Tyler. 2011. Calibrating single-ended fiber-optic Raman spectra distributed temperature sensing data. Sensors 11 (11): 10859-10879.

Hayes, S.A., M.H. Bond, C.V. Hanson, E.V. Freund, J.J. Smith, E.C. Anderson, A.J. Ammann, and R.B. MacFarlane. 2008. Steelhead growth in a small central California watershed: Upstream and estuarine rearing patterns. Transactions of the American Fisheries Society 137 (1): 114-128.

Hayes, S.A., M.H. Bond, C.V. Hanson, A.W. Jones, A.J. Ammann, J.A. Harding, A.L. Collins, J. Perez, and R.B. MacFarlane. 2011. Down, up, down and "smolting" twice? Seasonal movement patterns by juvenile steelhead (Oncorhynchus mykiss) in a coastal watershed with a bar closing estuary. Canadian Journal of Fisheries and Aquatic Sciences 68 (8): 1341-1350.

Hays, G.C. 2003. A review of the adaptive significance and ecosystem consequences of zooplankton diel vertical migrations. Hydrobiologia 503: 163-170.

Heady, W.N., R.P. Clark, K. O'Connor, C. Clark, C. Endris, S. Ryan, and S. Stoner-Duncan. 2015. Assessing California's bar-built estuaries using the California rapid assessment method. Ecological Indicators 58: 300-310.

Hicks, M. 2000. Evaluating standards for protecting aquatic life in Washington's surface water quality standards, draft discussion paper and literature summary. Revised 2002. Washington State Department of Ecology. Olympia, WA. Pub. No. 00-10-070, Washington State Department of Ecology, Olympia, WA. https:// fortress.wa.gov/ecy/publications/documents/0010070.pdf. Accessed 1 Oct 2021.

Hokanson, K.E.F., C.F. Kleiner, and W.W. Thorslund. 1977. Effects of constant temperatures and diel temperature fluctuations on specific growth and mortality rates and yield of juvenile rainbow trout, Salmo gairdneri. Journal of the Fisheries Research Board of Canada 34: 639-648.

Huang, P., K. Hennig, J. Kala, J. Andrys, and M.R. Hipsey. 2020. Climate change overtakes coastal engineering as the dominant driver of hydrological change in a large shallow lagoon. Hydrology and Earth System Sciences 24: 5673-5697.

Huber, E.R., and S.M. Carlson. 2020. Environmental correlates of finescale juvenile steelhead trout (Oncorhynchus mykiss) habitat use and movement patterns in an intermittent estuary during drought. Environmental Biology of Fishes 103 (5): 509-529.

Hyatt, K.D. 1980. Mechanisms of food resource partitioning and the foraging strategies of rainbow trout (Salmo gairdneri) and kokanee (Oncorhynchus nerka) in Marion Lake British Columbia. University of British Columbia.

Kammerer, B.D., and S.A. Heppell. 2013. The effects of semichronic thermal stress on physiological indicators in steelhead. Transactions of the American Fisheries Society 142 (5): 1299-1307.

Keeley, E.R. 2001. Demographic responses to food and space competition by juvenile steelhead trout. Ecology 82 (5): 1247-1259.

Landler, L., G.D. Ruxton, and E.P. Malkemper. 2019. The HermansRasson test as a powerful alternative to the Rayleigh test for circular statistics in biology. BMC Ecology 19 (1): 30.

Lebreton, J.-D., K.P. Burnham, J. Clobert, and D.R. Anderson. 1992. Modeling survival and testing biological hypotheses using marked animals: A unified approach with case studies. Ecological Monographs 62 (1): 67-118.

Lill, A.W.T., M. Schallenberg, A. Lal, C. Savage, and G.P. Closs. 2013. Isolation and connectivity: Relationships between periodic connection to the ocean and environmental variables in intermittently closed estuaries. Estuarine Coastal and Shelf Science 128: 76-83.

Lisle, T.E. 1987. Using residual depths to monitor pool depths independently of discharge Res. Note PSW-RN-394. U.S. Department of
Agriculture, Forest Service, Pacific Southwest Forest and Range Experiment Station. Berkeley, CA.

Lusardi, R.A., B.G. Hammock, C.A. Jeffres, R.A. Dahlgren, and J.D. Kiernan. 2020. Oversummer growth and survival of juvenile coho salmon (Oncorhynchus kisutch) across a natural gradient of stream water temperature and prey availability: An in situ enclosure experiment. Canadian Journal of Fisheries and Aquatic Sciences 77 (2): 413-424.

Malcolm-White, E., C.R. McMahon, and L.L.E. Cowen. 2020. Complete tag loss in capture-recapture studies affects abundance estimates: An elephant seal case study. Ecology and Evolution 10 (5): 2377-2384.

Martin, J.A. 1995. Food habits of some estuarine fishes in a small, seasonal central California lagoon. San Jose: San Jose State University Master's thesis.

McSweeney, S.L., D.M. Kennedy, I.D. Rutherfurd, and J.C. Stout. 2017. Intermittently Closed/Open Lakes and Lagoons: Their global distribution and boundary conditions. Geomorphology 292: 142-152.

Moyle, P.B., J.D. Kiernan, P.K. Crain, and R.M. Quiñones. 2013. Climate change vulnerability of native and alien freshwater fishes of California: A systematic assessment approach. PLoS ONE 8 (5): e63883.

Myrvold, K.M., and B.P. Kennedy. 2015. Interactions between body mass and water temperature cause energetic bottlenecks in juvenile steelhead. Ecology of Freshwater Fish 24 (3): 373-383.

National Marine Fisheries Service. 2012. Final recovery plan for central California coast coho salmon evolutionarily significant unit. Santa Rosa: National Marine Fisheries Service.

National Marine Fisheries Service. 2016. Final coastal multispecies recovery plan. Santa Rosa: National Marine Fisheries Service.

Nielsen, J.L., T.E. Lisle, and V. Ozaki. 1994. Thermally stratified pools and their use by steelhead in northern California streams. Transactions of the American Fisheries Society 123 (4): 613-626.

Nylen, B.D. 2015. Mouth closure and dissolved oxygen levels in a small, bar-built estuary: Scott Creek, California. Davis: University of California at Davis Master's thesis.

Osterback, A.-M.K., D.M. Frechette, S.A. Hayes, M.H. Bond, S.A. Shaffer, and J.W. Moore. 2014. Linking individual size and wild and hatchery ancestry to survival and predation risk of threatened steelhead (Oncorhynchus mykiss). Canadian Journal of Fisheries and Aquatic Sciences 71 (9): 1877-1887.

Osterback, A.-M.K., D.M. Frechette, A.O. Shelton, S.A. Hayes, M.H. Bond, S.A. Shaffer, and J.W. Moore. 2013. High predation on small populations: Avian predation on imperiled salmonids. Ecosphere 4 (9): 1-21.

Osterback, A.M.K., C.H. Kern, E.A. Kanawi, J.M. Perez, and J.D. Kiernan. 2018. The effects of early sandbar formation on the abundance and ecology of coho salmon (Oncorhynchus kisutch) and steelhead trout (Oncorhynchus mykiss) in a central California coastal lagoon. Canadian Journal of Fisheries and Aquatic Sciences 75 (12): 2184-2197.

Ostrovsky, I. 1995. The parabolic pattern of animal growth: Determination of equation parameters and their temperature dependencies. Freshwater Biology 33 (3): 357-371.

Perissinotto, R., D.D. Stretch, A.K. Whitfield, J.B. Adams, A.T. Forbes, and N.T. Demetriades. 2010. Temporarily open/closed estuaries in South Africa. In Estuaries: Types movement patterns and climatic impacts, ed. J.R. Crane and A.E. Solomon, 1-69. New York: Nova Science.

Quiñones, R.M., and T.J. Mulligan. 2005. Habitat use by juvenile salmonids in the Smith River estuary California. Transactions of the American Fisheries Society 134 (5): 1147-1158.

R Development Core Team. 2019. R: A language and environment for statistical computing. R Foundation for Statistical Computing, Vienna, Austria. https://www.R-project.org. Accessed 1 Oct 2021. 
Richards, C., O. Moal, and C. Pallud. 2018. Changes in water quality following opening and closure of a bar-built estuary (Pescadero California). Marine Chemistry 198: 10-27.

Richter, A., and S.A. Kolmes. 2005. Maximum temperature limits for Chinook, coho, and chum salmon, and steelhead trout in the Pacific Northwest. Reviews in Fisheries Science 13 (1): 23-49.

Robinson, M.A. 1993. The distribution and abundance of benthic and epibenthic macroinvertebrates in a small, seasonal central California lagoon. San Jose: San Jose State University Master's thesis.

Satterthwaite, W.H., S.A. Hayes, J.E. Merz, S.M. Sogard, D.M. Frechette, and M. Mangel. 2012. State-dependent migration timing and use of multiple habitat types in anadromous salmonids. Transactions of the American Fisheries Society 141 (3): 781-794.

Scheuerell, M.D., and D.E. Schindler. 2003. Diel vertical migration by juvenile sockeye salmon: Empirical evidence for the antipredation window. Ecology 84 (7): 1713-1720.

Schwarz, C.J., and A.N. Arnason. 1996. A general methodology for the analysis of capture-recapture experiments in open populations. Biometrics 52 (3): 860-873.

Selker, J.S., N.C. van de Giesen, M. Westhoff, W. Luxemburg, and M.B. Parlange. 2006a. Fiber optics opens window on stream dynamics. Geophysical Research Letters 33 (24).

Selker, J.S., L. Thévenaz, H. Huwald, A. Mallet, W. Luxemburg, N. Van De Giesen, M. Stejskal, J. Zeman, M. Westhoff, and M.B. Parlange. 2006b. Distributed fiber-optic temperature sensing for hydrologic systems. Water Resources Research 42 (12).

Shapovalov, L., and A.C. Taft. 1954. The life histories of the steelhead rainbow trout (Salmo gairdneri gairdneri) and silver salmon (Oncorhynchus kisutch). California Department of Fish and Game, Fish Bulletin 98.

Sloat, M.R., and A.-M.K. Osterback. 2013. Maximum stream temperature and the occurrence, abundance, and behavior of steelhead trout (Oncorhynchus mykiss) in a southern California stream. Canadian Journal of Fisheries and Aquatic Sciences 70 (1): 64-73.

Smith, J.J. 1990. The effects of sandbar formation and the inflows on aquatic habitat and fish utilization in Pescadero, San Gregorio, Waddell and Pomponio Creek estuary/lagoon systems, 1985-1989. Prepared for California Department of Parks and Recreation, Interagency Agreement 84-04-324, San Jose State University. https:// calisphere.org/item/ark:/86086/n2f47n1b/. Accessed 1 Oct 2021.

Sullivan, K., D.J. Martin, R.D. Carwell, J.E. Toll, and S. Duke. 2000. An analysis of the effects of temperature on salmonids of the
Pacific Northwest with implications for selecting temperature criteria. Sustainable Ecosystems Institute. Portland, OR, USA. http:// www.krisweb.com/biblio/gen_sei_sullivanetal_2000_tempfinal. pdf. Accessed 1 Oct 2021.

Torgersen, C., J. Ebersole, and D. Keenan. 2012. Primer for identifying cold-water refuges to protect and restore thermal diversity in riverine landscapes. Seattle: US Environmental Protection Agency.

Tyler, S.W., J.S. Selker, M.B. Hausner, C.E. Hatch, T. Torgersen, C.E. Thodal, and S.G. Schladow. 2009. Environmental temperature sensing using Raman spectra DTS fiber-optic methods. Water Resources Research 46 (4).

United States Environmental Protection Agency. 2003. EPA Region 10 Guidance for Pacific Northwest State and Tribal Temperature Water Quality Standards. EPA 910-B-03-002. Seattle: US Environmental Protection Agency.

United States Naval Observatory. 2011. MICA: Multiyear interactive computer almanac 1800-2050, version 2.2.2.

Viant, M.R., I. Werner, E.S. Rosenblum, A.S. Gantner, R.S. Tjeerdema, and M.L. Johnson. 2003. Correlation between heat-shock protein induction and reduced metabolic condition in juvenile steelhead trout (Oncorhynchus mykiss) chronically exposed to elevated temperature. Fish Physiology and Biochemistry 29 (2): 159-171.

Wangila, B.C.C., and T.A. Dick. 1988. Influence of genotype and temperature on the relationship between specific growth rate and size of rainbow trout. Transactions of the American Fisheries Society 117 (6): 560-564.

Watson, B.M., C.A. Biagi, S.L. Northrup, M.L.A. Ohata, C. Charles, P.J. Blanchfield, S.V. Johnston, P.J. Askey, B.T. van Poorten, and R.H. Devlin. 2019. Distinct diel and seasonal behaviours in rainbow trout detected by fine-scale acoustic telemetry in a lake environment. Canadian Journal of Fisheries and Aquatic Sciences 76 (8): 1432-1445.

Werner, I., T.B. Smith, J. Feliciano, and M.L. Johnson. 2005. Heat shock proteins in juvenile steelhead reflect thermal conditions in the Navarro River watershed California. Transactions of the American Fisheries Society 134 (2): 399-410.

White, G.C., and K.P. Burnham. 1999. Program mark: Survival estimation from populations of marked animals. Bird Study 46: S120-S139.

Williams, K.A., P.C. Frederick, and J.D. Nichols. 2011. Use of the superpopulation approach to estimate breeding population size: An example in asynchronously breeding birds. Ecology 92 (4): $821-828$. 